UDK 272-732(497.58)“1579”(091)

272-9(497.5)“15”

Pregledni rad

Primljeno: 26. kolovoza 2020.

Prihvaćeno za objavljivanje: 4. prosinca 2020.

\title{
POKRAJINSKI SABOR JUŽNOHRVATSKIH BISKUPIJA U ZADRU 1579. GODINE
}

\author{
Zvjezdan STRIKA \\ Bistum Augsburg \\ Herbststraße 2b, 86456 Gabilingen, Deutchland \\ ZStrika@gmx.de
}

U radu se prikazuje krajevni sabor, koji je u benediktinskom samostanu sv. Krševana dan ili dva prije 20. svibnja 1579. godine sazvao apostolski pohoditelj, veronski biskup Agostino Valier (1531. - 1606.). Njemu je papa Grgur XIII. (1572. - 1585.) povjerio vizitaciju područja istočnojadranske obale pod mletačkom upravom. Kada je obavio velik dio povjerene mu zadaće stigao je početkom svibnja sa svojim suradnicima u Zadar, gdje je pomno pripremio saborsko zasjedanje. Na njemu se raspravljalo o mnogobrojnim problemima s kojima se susretala Crkva u Dalmaciji. Saborske konstitucije imaju devet poglavlja koje se sadržajno jedna na drugu skladno nadovezuju i sačinjavaju jednu homogenu cjelinu. One su inspirirane smjernicama Tridentskog sabora (1545. - 1563.), a prilagođene su konkretnoj situaciji u mletačkoj Dalmaciji, koja je s jedne strane pritješnjena osmanskim susjedstvom, a s druge strane, mletačka uprava pokušavala je podrediti crkvene institucije svojim vlastitim političkim interesima.

KLJUČNE RIJEČI: Zadar, Crkva pod mletačkom upravom, apostolska vizitacija, pokrajinski sabor, apostolski pohoditelj Agostino Valier, rani novi vijek.

\section{Uvod}

S ciljem djelotvornije obnove crkvenih struktura na istočnojadranskoj obali, kojim je vladala Venecija, poslao je papa Grgur XIII. (1572. - 1585.) pohoditelja, veronskoga biskupa i kasnijeg kardinala Agostina Valiera (1531. - 1606.). Taj visoki dostojanstvenik je s puno mara i brige obišao područje od Budve na Jugu pa sve do Osora i Krka na Sjeveru. Došavši u Zadar 1. svibnja 1579. godine, obišao je osobno neke župe koje su smještene pod mletačkom upravom, a druge su obišli njegovi najbliži surdanici. Ujedno je pozvao sve nad/biskupe na krajevni sabor, koji je zasjedao u benediktinskom samostanu sv. Krševana dan ili dva prije 20. svibnja 1579. godine. Njega je apostolski vizitator Valier pomno pripremio. U sinodalnim konstitucijama se osjeća njegov utjecaj i njegov pogled na konkretne crkvene strukture, ali isto tako nije se zapostavila ni situacija u kojoj su se nalazile crkvene institucije u mletačkoj Dalmaciji. One su po odredbi 
apostolskog pohoditelja odmah tiskane, ${ }^{1}$ a nadbiskupi, biskupi, svećenici i redovnici su ih trebali pomno studirati te provoditi u konkretnu praksu. Reforma se nije zaustavljala samo na izvanjskoj ritualnoj praksi nego stvarnoj katoličkoj obnovi (metanoia), koja se trebala provoditi s redovnim vizitacijama, godišnjim održavanjem dijecezanskih sinoda i trogodišnjim sazivanjem metropolitanskih sabora. ${ }^{2}$ Pokrajinski sabor 1579 . godine sadržajno se svjesno naslanja na tridentske smjernice, dajući im konkretne impulse za daljnji razvoj sinodalnosti na razini biskupija i metropolija.

Povjesničari su zapazili važnost Valierove vizitacije i osobito veliko značenje podataka koje je veronski biskup pribilježio u svojem izvješću, koje je odmah poslije svoje misije podnio Svetoj Stolici. ${ }^{3}$ Njime su se do danas služili mnogi znanstvenici. Sva njihova imena nije moguće na ovom mjestu spomenuti, ${ }^{4}$ ali među njima se posebno ističe Ivan Vitezić svojim doktorskim radom ${ }^{5}$ i Velimir Blažević u svojem prikazu koncilske tradicije kod Hrvata. ${ }^{6}$ Mnogobrojni autori donose podatke iz izvješća o pojedinim biskupijama ili drugim crkvenim institucijama: Mario Pavat se osvrnuo na reformu u Puli i Poreču, ${ }^{7}$ a samo godinu dana kasnije Valierovom vizitacijom otoka Hvara intenzivnije se pozabavio Davor Domančić. ${ }^{8}$ Amos Rube Filipi je na temelju nje prikazao situaciju Ninske crkve i benediktinsku opatiju svete Marije u Zadru, ${ }^{9}$ a na temelju Valierova

1 Constitutiones et decreta in conventu Reveren. DD. Spalatensis et Jadrensis provinciae Archiepiscoporum et Episcoporum, ac eorum assensu a Reverendissimo D. Augustino Valerio, Veronen. Episcopo Visitatore Dalmatiae et Reformatore Apostolico promulgata et a Sede Apostolica confirmata, Vicenza, 1579. Djelo je danas rijetko dostupno pa se uobičajeno saborski zaključci navode prema: Daniele FARLATI, Illyricum sacrum, sv. 5, Venetiis, 1775., str. 132-139. Originalni primjerak sinodalnih odluka pohranjem je u Arhivu Hvarske biskupije. Arhiv Capituli Pharensis, KAH VIa/6; Velimir BLAŽEVIĆ, Concilia et synodi in territorio hodiernae Jugoslaviae celebrata, Vicetiae, 1967., str. 52; IsTI, »Crkveni partikularni sabori i dijecezanske sinode na području Hrvatske i drugih južnoslavenskih zemalja«, Croatica Christiana - Fontes, sv. 28, Zagreb, 2012., str. 106. O samom saboru usp. još i Carlo F. BIANCHI, Zara cristiana, sv. I, Zara, 1877., str. 25; Francesco SALATA, L'antica diocesi di Ossero et la liturgia slava, Pola, 1897., str. 83-84; Ivan VITEZIĆ, La prima visita apostolica posttridentina in Dalmazia (nell'anno 1579) [excerpti, ex dissertatione ad lauream], Romae, 1957., str. 40-42; Zvjezdan STRIKA, »Zadarske sinode u svjetlu povijesnih vrela«, Sedamnaest stoljeća Zadarske crkve. Zbornik radova sa znanstvenog skupa o 1700. godišnjici mučeništva sv. Stošije (Anastazije), Zadar, 16.-18. studenog 2004., sv. I: Od ranokršćanskog razdoblja do pada Mletačke Republike, Livio MARIJAN (ur.), Zadar, 2009., str. 45-104, ovdje str. 83-86.

$2 \mathrm{Na}$ ovom mjestu ukazujem samo na pregled dijecezanskih sinoda na hrvatskome govornom području koje su zasjedale poslije Tridenskog sabora do Sabora u Zadru 1579. godine. Njihov redoslijed donosi V. BLAŽEVIĆ, Concilia et synodi, str. 73-82; IsTI, Crkveni partikularni sabori, str. 140-160 i ponajviše na temelju njegova prikaza Daniel PATAFTA - Slavko SLIŠKOVIĆ, »Dijecezanske sinode - primjer provođenja posttridentske obnove«, Tridentska baština. Katolička obnova i konfesionalizacija u hrvatskim zemljama. Zbornik radova, Zrinka BLAŽEVIĆ - Lahorka PLEJIĆ POJE (ur.), Zagreb, 2016., str. 121-140.

3 Biskup Valier je poslije vizitacije podnio Svetoj Stolici detaljno izvješće o stanju Crkve u mletačkoj Dalmaciji. Visitatio Apost. Dalmatiae, Visitatio Iadrensis anno 1579, AAV, cod. 413A, fol. $1^{\mathrm{r}}-152^{\mathrm{v}}$.

4 Kratki pregled donosi Tea PERINČIĆ, »Prilog istraživanju apostolskih vizita Agostina Valiera u dalmatinskim i istarskim biskupijama«, Povijesni prilozi, br. 17, Zagreb, 1998., str. 157-176.

5 Usp. ovdje bilj. 1

6 V. BLAŽEVIĆ, Concilia et synodi, str. 51-53; ISTI, Crkveni partikularni sabori, str. 105-107.

7 Mario PAVAT, La riforma tridentina del clero a Parenzo e Pola nei secoli XVI-XVIII, Dissertatio ad lauream in Facultate Iur. Canon. Pont. Universitatis Gregorianae, Romae, 1960.

8 Davor DOMANČIĆ, »Valijerova vizitacija na otku Hvaru i Visu«, Arhivska građa otoka Hvara, br. 1, Hvar, 1961., str. 7-58.

9 Usp. Amos Rube FILIPI, "Samostan i crkva sv. Marije u Zadru prema dokumentima iz godine 1579. i 1603.«, Kulturna baština Samostana svete Marije u Zadru, Radovi Instituta JAZU u Zadru, sv. 13-14, Grga NOVAK - Vjekoslav MAŠTROVIĆ (prir.), Zadar, 1967., str. 231-266; Amos Rube FILIPI, »Ninske crkve 
izvještaja donosi Radovan Ivančević nastariji opis paške zborne crkve sv. Marije, koju je vizitator obišao 24. svibnja 1579. godine. ${ }^{10}$ Atanazije J. Matanić ukratko je prikazao Korčulansku biskupiju s posebnim osvrtom na župu Blato. ${ }^{11} \mathrm{U}$ sklopu Valjerove vizitacije, Tršćanske dijeceze koju je proveo po nalogu pape Grgura XIII., ukazali su Loreno i Mary Madeline Tacchella na njegov boravak u mletačkoj Dalmaciji. ${ }^{12}$ Tea Perinčić je u svojem magistarskom radu iscrpno prikazala vizitaciju Rapske biskupije, ${ }^{13}$ a o Valierovu boravku u gradu Šibeniku donosi iz njegova izvještaja navažnije podatke Jadranka Neralić. ${ }^{14}$ Vojko Mardešić i Slavko Kovačić objavili su tekstove Valijerove vizitacije koji se odnosi na Hvarsku biskupiju. ${ }^{15}$

\section{Pogled na konkretnu stvarnost}

Djelotvornije provođenje obnove svekolike crkvene prakse na uskom pojasu istočnojadranske obale koja se nalazila pod mletačkom upravom bilo je otežano, i to osobito zbog napetih gospodarskih i političko-socijalnih neprilika. S jedne strane takvom je stanju pogodovala centralna mletačka vlada koja nije nikada službeno prihvatila odluke Tridentskoga koncila (1545. - 1563.), ${ }^{16}$ a s druge strane su Osmanlije, koji su poslije zauzimanja današnje Bosne i Hercegovine mogli na dugoj granici i dalje prodirati $u$ hrvatske krajeve. ${ }^{17}$

u dokumentima iz godine 1575. i 1603.«, Povijest grada Nina, Grga NOVAK - Vjekoslav MAŠTROVIĆ (prir.), Zadar, 1969., str. 549-596.

${ }_{10}$ Radovan IVANČEVIĆ, »Najstariji opis paške zborne crkve: vizitacija Augustina Valiera 1579. godine«, Peristil, br. 25, Zagreb, 1982., str. 81-86.

${ }^{11}$ Usp. Atanazije J. MATANIĆ, »Prilog povijesti Korčulanske biskupije. Apostolska vizitacija nekadašnje Korčulanske biskupije godine 1579, s posebnim osvrtom na župu Blato«, Crkva u Svijetu, br. 23, Split, 1988., str. 392-397.

${ }^{12}$ Lorenzo TACCHELLA, Mary Madeline TACCHELLA, Il cardinal Agostino Valier e la riforma tridentina nelle diocese di Trieste, Udine, 1974., str. 83-87.

13 Tea PERINČIĆ, Rapska biskupija u vizitaciji Augustina Valiera 1579. godine, Magistarski rad, Zagreb, 2004.

${ }_{14}$ Jadranka NERALIĆ, »Slike iz svakodnevnoga života u Šibeniku prema vizitaciji apostolskog vizitatora Agostina Valiera 1579. godine«, Faust Vrančić i njegovo doba. Zbornik radova s Međunarodnoga znanstvenoga skupa održanoga u povodu 400. obljetnice objavljivanja Novih strojeva Fausta Vrančića. Vodice - Šibenik, 22-23. rujna 2015., Mirja BORIĆ - Zrinka BLAŽEVIĆ - Bojan MAROTTI (prir.), Prvić Luka, 2018., str. 187-218.

15 Usp. Andrija Vojko MARDEŠIĆ - Slavko KOVAČIĆ, Spisi apostolskih vizitacija dalmatinskih biskupija. Spisi apostolskih vizitacija Hvarske biskupije iz 1579., 1602./03., i 1624./25., Roma, 2005.

${ }^{16} \mathrm{U}$ obilju literature ukazujem samo na ovdje u bilješci 2 već prije spomenuti zbornik Tridentska baština i Hubert JEDIN, Geschichte des Konzils von Trient, sv. I-IV, Freiburg i. Br., 1949.-1975.; Concilium Tridentinum (1545-1563), Wege der Forschung, 313, (prir Regimius BÄUMER), Darmstadt, 1979.; Charles LEFEBVRE, Lateran V und Trient (1 Teil), Geschichte der Ökumenischen Konzilien, 10, Mainz, 1978., str. 181-453; Joseph LECLER - Henri HOLSTEIN - Pierre ADNÈS - Charles LEFEBVRE, Trient II, Geschichte der Ökumenischen Konzilien, 11, Mainz, 1987., str. 17-704; Marc VENARD, »Das fünfte Laterankonzil (1512/1517) und das Konzil von Trient (1545/1563)«, Geschichte der Konzilien. Vom Nicaenum bis zum Vaticanum II, Giuseppe ALBERIGO, (prir.) Düsseldorf, 1993. (pretisak Wiesbaden, 1998.), str. 333-383; Das Konzil von Trient im ökumenischen Gespräch, die Katholische Akademie Hamburg (prir.), Hamburg, 1996.; Klaus GANZER, Čl.: Trient, Lexikon für Theologie und Kirche, 10, Freiburg - Basel - Roma - Wien, 2001. (pretisak, 2009.), str. 225 - 231; Ivica MUSA, »Tridentski sabor - koncil među koncilima?«, Tridentska baština, str. 17-30.

${ }_{17}$ Pregled osmanskih prodiranja i zazimanja hrvatskog teritorija donosi Milorad Pavić, Jugoistočna Europa pod osmanskom vlašću. Od pada Carigrada do Svištovskog mira, Zadar, 2014., str. 174-196. 
Mletačka vlast je odmah nakon što se uspjela dočepati istočnojadranske obale, provodila državnu centralizaciju na novozadobivenom području i ona »nije nikada smatrala Dalmaciju ravnopravnim dijelom svoje države, nego kolonijalnim područjem koje treba držati u neznanju i zaostalosti kako se jednoga dana ne bi osamostalilo ${ }^{18}$. Crkvene službe, pa čak i velike vjerske svečanosti su u tom društveno-političkom i gospodarskom kontekstu imale izvanredno važnu ulogu. Na primjeru Zadra i njegove Crkve očigledna je mletačka politika prema crkvenim institucijama u cijeloj Dalmaciji. Pod utjecajem državne administracije širilo se u samom Zadru štovanje „,novih svetaca”, npr. sv. Roko i osobito sv. Marko Evanđelist (31. srpnja), čije slavljenje je uvedeno na spomen ulaska mletačke vojske u Zadar 1409. godine. U kalendaru zadarske stolne crkve iz 15. stoljeća svetkovina je unesena »crvenom bojom i liturgijskom kvalifikacijom duplex minus .... Slavila se svečanom misom i procesijom u kojoj su morali sudjelovati kanonici Kaptola, sav gradski kler, seoski župnici od Kukljice do Ugljana i od Kožina do Sukošana, zatim bratovštine, obrtničke skule, sve redovničke zajednice, vojna posada i gradsko predstavništvo. Procesija je polazila od katedrale a zaustavljala bi se kod gradske lože, gdje su se izgovarale posebne molitve za dobrobit Mletačke Republike. Procesija se nije nikad smjela izostaviti ${ }^{19}$

Upravo izneseni podatak pokazuje koliku je važnost pridavala mletačka vlast utjecaju Crkve, njenih institucija i vjerskih manifestacija na obični puk. Dukalom od 17. lipnja 1423. godine odredila je precizno da u Dalmaciji mogu zasjesti na biskupska sjedišta samo one osobe koje su vjerne i odane Republici. ${ }^{20}$ Za njeno provođenje oni nisu spremni na bilo kakve kompromise s Rimskom kurijom. Od nadbiskupa Luke Turina iz Ferma (1400. - 1419.) koji je intenzivno sudjelovao u pripremi sabora u Konstanzu na Bodenskom jezeru (1414. - 1418.), pa sve do nadbiskupa Vicka Zmajevića (1713. - 1745.) - dakle u razdoblju od tri stotine godina - svi su zadarski nadbiskupi došli s mletačkih laguna, njene okolice ili njena upravnog područja. Njihova nacionalna i regionalna pripadnost osjećala se u neprimjernoj komunikaciji s vjernicima jer većina njih nije dovoljno poznavala hrvatski jezik da bi s njima mogli komunicirati. Oni su poslije nadbiskupa Vallaressa pa sve do nadbiskupa Mucija Callinija (1555. - 1566.) ponajviše djelovali u Rimu ili Veneciji primajući svoje komendatorske prihode: nadbiskupi, Aleksandar II. (1503. - 1504.), Ivan Cippico (1503. - 1504.), Alojzije Cippico (1504. - 1505.), kardinal Egedije Canini iz Viterba (1530. - 1532.), Kornelije Pisanski (1533. - 1554.) i kardinal Alojzije Cornaro (1554. - 1555.) nisu, koliko je danas poznato, nikada posjetili Zadar. ${ }^{21}$ Takva praksa po-

18 Stjepan KRASIĆ, Generalno učilište dominikanskoga reda u Zadru ili Universitas Jadertina (1396.-1807.), Zadar, 1996., str. 229.

${ }_{19}$ Marijan GRGIĆ, »Kalendar zadarske stolne crkve iz 15. stoljeća«, Radovi Instituta JAZU u Zadru, br. 20, Grga NOVAK - Vjekoslav MAŠTROVIĆ (prir.), Zadar, 1973., str. 119 - 174, ovdje str. 141. U kalendaru je unesen na 31. siječnja i blagdan prijenosa relikvija sv. Marka (translatio sancti Marci evangelistae), koji je isto tako uveden u Zadar tek poslije 1409. godine.

${ }^{20}$ Senat je u Veneciji odlučio da pro nostro dominio et securitate civitatum nostrarum Dalmatiae, pro evitandis suspitionibus et inconvenientiis, quae sequi possent, quod in episcopatibus dictarum terrarum nostrarum Dalmatiae non sint nisi nostri veneti... Šime LuUBIĆ, Listine o odnošajih Južnoga Slavenstva i Mletačke republike, knjiga 8, MSHSM, 8, Zagreb, 1886., str. 231; Ivan PEDERIN, Mletačka uprava, privreda i politika u Dalmaciji (1409. - 1797.), Dubrovnik, 1990., str. 32.

${ }^{21} \mathrm{Na}$ temelju Farlatija i Vitezića dokazuje Stjepan Krasić da je Zadarska crkva imala više nadbiskupa koji nisu nikada stupili nogom na tlo nadbiskupije. D. FARLATI, Illyricum sacrum, sv. 5, str. 123-27; Stjepan 
kazala se neprimjernom, dapače štetnom za razvoj crkvene prakse, a vlada je u Mlecima, kako bi uspjela uvjeriti pojedine pape i njihove najbliže suradnike $u$ ispravnost svojih namjera, bez prestanka isticala važnost grada Zadra kao upravnoga centra za njeno postojanje, a zbog toga su na nadbiskupskoj stolici trebali zasjedati samo ljudi od njezina osobitog povjerenja.

U takvu situaciju umješale su se i Osmanlije, koji su prodirali prema Zapadu. Zauzimanjem Klisa 1537. godine oni su se primakli samom Splitu, a mletačko-otomanski rat 1570. - 1573. godine (tzv. Ciparski rat) opustošio je cijelu Dalmaciju, premda se rat usredotočio na sredozemni otok Cipar. Osmanska granica bila je nadomak Splita, a njene straže bile su smještene u Solinu i Kamenu, dakle »samo sat hoda od grada. Takvo stanje je potrajalo 111 godina, dakle sve do 1648 . kada je Klis bio osloboden od Turaka «22. Makarska biskupija našla se u kud i kamo težem položaju negoli Splitska crkva. Nju su Osmanlije zauzeli koncem 15. stoljeća, a biskupska stolica je ostala upražnjena sve do drugog desetljeća 17. stoljeća, kada je Rim otpočeo ponovno imenovati biskupe. ${ }^{23}$ Istu sudbinu dijelila je Kninska i Skradinska biskupija, jer su oba grada, Knin i Skradin, 1522. godine pala u osmanske ruke. Situacija se sljedećih stotinu i pedeset godina nije znatnije promjenila, dapače ona se sa što duljom osmanskom vlašću iz dana u dan pogoršavala. Sveta Stolica je uvidjela potrebu intenzivnije biskupijske kontrole i nakon oslobađanja 1688. godine dokinula je Kninsku biskupiju. Njen teritorij pripojen je Šibenskoj crkvi. Tri otočne biskupije, Krk, Rab i Osor, isto tako su osjećale negativne posljedice osmanske prisutnosti. Njihovi stanovnici nisu mogli više nesmetano izvoziti svoje proizvode prema Velebitu i unutrašnjosti pa su i oni gospodarski nazadovali.

Zadarska i Ninska crkva su tijekom ratnih sukoba stradale, zauzete su 1570 . godine važne utvrde Zemunik i Poličnik, tako da se granica primakla samim biskupijskim centrima. Ona je od Zadra bila udaljena svega tri milje, župu Dračevac (danas sjeveroistočni dio grada Zadra) zauzeli su Osmanlije, a prve godine rata pučanstvo Zadra nije skupilo ni jedno zrno žita, nego su to uradili Osmanlije koji su zaposjeli njegovu okolicu. Seljaci iz obližnjih mjesta bili su prisiljeni svaku večer dolaziti sa svojim stadima u grad i ujutro se vraćati na svoja polja. Njih su zbog neprestane osmanske opasnosti uvijek pratile dvije kompanije stratiota. ${ }^{24} \mathrm{Uz}$ te mjere vlada je 1570 . godine iz strateških razloga naredila sječu svih maslina u okolici Zadra, a ostatak su dokrajčili osmanski plaćenici 1580. i 1586. godine. Druge privredne grane kao što su npr. žitnice, vinogradarstvo ili stočarstvo znatno su narušene tako da je stanovništvo često gladovalo, a što je još gore pojavljivale su se razne zarazne bolesti, osobito kuga. ${ }^{25}$

KRASIĆ, Počelo je u Rimu. Katolička obnova i normiranje hrvatskoga jezika u XVII. stoljeću, Dubrovnik, 2009., str. 155; Zvjezdan STRIKA, "„Catalogus episcoporum et archiepiscoporum urbis Iadertinae” arhiđakona Valerija Pontea«, Radovi Zavoda za povijesne znanosti HAZU u Zadru, br. 48, Zagreb - Zadar, 2006., str. 81 - 185, ovdje str. 166 - 182.

${ }^{22}$ Mile VIDOVIĆ, Povijest crkve u Hrvata, Split, 1996., str. 145.

${ }_{23}$ Karlo JURIŠIĆ, Katolička crkva na biokovsko-neretvanskom području za turske vladavine, Zagreb, 1972. str. 38 .

${ }^{24}$ Tako opisuje situaciju Zadra i njegova područja u svojoj relaciji Andrija Giustiniani i Oktavian Valier poslije povratka s dužnosti sindika 1576. godine. Commissiones et relationes Venetae, tomus 4: annorum 15721590, MSHSM, sv. 47, Grga NOVAK (prir.), Zagreb, 1964., str. 175-179.

${ }^{25}$ Usp. Šime PERIČIĆ, Razvitak gospodarstva Zadra i okolice u prošlosti, Zagreb - Zadar, 1999., str. 78-81. 
Stalna opasnost i mogući otomanski napadi na granici osjećali se na svakom koraku pa je mletačka vlada pokušavala preduhitriti depopulaciju uskog zadarsko-ninskog zaleđa. Nastojeći napučiti opustjele krajeve u bližoj okolici Zadra i Nina, velikodušno je oprostila krivice svim prognanim osobama iz Dalmacije, pozivajući ih neka se povrate na svoja stara ognjišta. ${ }^{26}$ Ujedno je pozivala i stanovnike s otomanskog područja neka se presele sa svojim obiteljima na teritorij pod njenom vlašću. O stvarnosti situacije i strahu u duši hrvatskog čovjeka zorno svjedoči izvješće iz 1578. godine, koje je podnio Alvis Dolfin nakon povratka s dužnosti zadarskoga kneza. Osmanlije su, prema njegovu izvješću, često robili ljude, otimali su osobito djecu da bi ih potom prodavali njihovim roditeljima ili najbližim rođacima, ukoliko su mogli pribaviti zahtijevanu novčanu sumu. ${ }^{27}$ Upravo zbog tako teških životnih uvjeta jako mali broj mjesta u zadarsko-ninskom zaleđu bio je naseljen. Među njima su samo naseljeni Nin, Novigrad, Posedarje, Ljubač, Vir, Pakoštane, Diklo, Stomorino, Sukošan, Turanj i Biograd. Veliko migracijsko kretanje stanovništva popratna je pojava osmanskih prodiranja te su ostala mjesta nenastanjena ili su ih već ranije Osmanlije opustošili. Velik dio stanovnika selio se na sigurnija područja (na otoke ili druga područja pod mletačkom upravom), a kada je opasnost djelomično jenjala, vraćao se na svoja stara i velikim dijelom opustošena ognjišta. ${ }^{28}$ Istodobno su u samom Zadru zbog obrane stracionirani mletački stratioti koji su dovedeni s drugoga državnog područja i djelomično su bili pravoslavne vjere. Oni su kao mletački državljani bili podređeni jurisdikciji filadelfijskog nadbiskupa u Mletcima i njima je zadarski nadbiskup Venier prepustio 1578. godine crkvu svetog Ilije Proroka za slavljenje liturgijskih obreda po bizantskom obredu. U crkvi je ipak ostao jedan ,latinski oltar” kako bi se na njemu i dalje mogla slaviti misa ,latinskim obredom”. ${ }^{29}$

\section{Dolazak apostolskog pohoditelja na istočnojadransku obalu}

Osmanska pritješnjenost osjećala se još više na pastoralnom području koje je po kopnenom zaleđu Splita, Trogira, Šibenika, Zadra i Nina svedeno na minimum, tj. na podjeljivanje sakramenata kršćanske inicijacije, od kojih je najčešće podijeljeno samo krštenje i sveta pričest. Biskupi su posjećivali župe na području pod osmanskom upravom samo sporadično i iznimnim slučajevima. Oni su redovno slali ad limina izvješća Svetoj Stolici, a opširno izvješće apostolskog vizitatora, biskupa veronskog i kasnijeg kardinala,

\footnotetext{
${ }^{26}$ Usp. Gligor STANOJEVIĆ, Jugoslovenske zemlje u mletačko-turskim ratovima 16.-18. vjeka, Beograd, 1970., str. 95.

${ }^{27}$ Roditelji i bliži rođaci često su s velikim svotama novca otkupljivali zarobljenike iz otomanskoga sužanjstva. U Državnom arhivu u Zadru pohranjeni su mnogobrojni podatci o sklopljenim ugovorima o otkupljivanju zarobljenika sa zadarsko-ninskog područja. Jedan veliki dio takvih ugovora odnosi se upravo na maloljetnu djecu koju su roditelji otkupljivali. Tomislav RAUKAR - Ivo PETRICIOLI - Franjo ŠVELEC - ك̌ime PERIČIĆ, Zadar pod mletačkom upravom 1409. - 1797., Zadar, 1987., str. 273.

${ }_{28}$ Commissiones et relationes Venetae, sv. 4, str. 224. T. RAUKAR - I. PETRICIOLI - F. ŠVELEC - ড̌. PERIČIĆ, Zadar pod mletačkom upravom, str. 369-370.

${ }^{29}$ C. F. BIANCHI, Zara cristiana, sv. 1, str. 451; Angelo de BENVENUTI, Storia di Zara dal 1409 al 1797, Milano, 1944., str. 129; Josip KOLANOVIĆ, »Zadarska nadbiskupija prema izvještajima ad limina 1599. - 1799.«, Sedamnaest stoljeća Zadarske crkve, str. 379 -413, ovdje str. 407; Josip VRANDEČIĆ, Zadarski nadbiskup Minuccio Minucci i njegova jadranska misija, Zagreb - Split, 2017., str. 194.
} 
Agostina Valiera (1565. - 1606.), ${ }^{30}$ koji je osobno pohodio Crkvu u Dalmaciji, predstavlja raritetni izvor ne samo za konkretnu prošlost Crkve i njenih institucija nego isto tako i za proučavanje društvene situacije, gospodarskih odnosa i socijalnih struktura na istočnojadranskoj obali. ${ }^{31}$

Sve neophodne pripreme za vizitaciju u Dalmaciji priredila je pravodobno Kongregacija za biskupe i redovnike. Dekret imenovanja potpisan je već 18. listopada 1578. godine, a svega dva dana kasnije javlja predstojnik iste Kongregacije kardinal Marcantonio Maffei (1521. - 1583.) apostolskom nunciju u Veneciji Albertu Bolognettiju (1538. - 1585.) da je papa Grgur XIII. imenovao veronskog biskupa Agostina Valiera apostolskim pohoditeljem istočnojadranskih biskupija pod mletačkom vlašću. ${ }^{32}$ Kardinal je priložio sve potrebne isprave s ovlastima i točnim uputama koje su mu trebale biti predane prije njegova polaska na istočnojadransku obalu. ${ }^{33}$ Istodobno ga je kardinal poticao neka ne odugovlači s putovanjem u mletačku Dalmaciju, nego neka što prije posjeti biskupije i neka podnese detaljan pismeni izveštaj o svojoj misiji. ${ }^{34}$

Biskup Valier je bio pogodna osoba za provođenje vizitacije u mletačkoj Dalmaciji. On je povjerenik pape Grgura XIII., a što je još vrlo važno Agostino je sposoban, učen i pouzdan biskup posttridentskog vremena koji se pokazao vrlo aktivnim u Veronskoj biskupiji. On je mletački građanin, koji je potjecao iz ugledne patricijske obitelji i kao takav, od državnih organa, manje ,sumnjiv” za povjerenu zadaću. Njega se smatralo čovjekom koji neće nanijeti štete mletačkoj vlasti u Dalmaciji. Mletačka državna uprava nije rado i s naklonošću gledala da rimska administracija, po vlastitom nahođenju šalje svoje vlastite legate na područje pod njenom upravom. Ona je poušavala imati sve pod svojom upravom i vlastitim osobljem kontrolirati situaciju. Upravo u tako isprepletenim konstelacijama između Rima i Venecije kretao se biskup Valier. Njemu su bili poznati odnosi mletačke vlade prema Rimskoj kuriji i kao revni zagovornik tridentske obnove shvatio je svoju zadaću ozbiljno i pokušao je provesti svjesno i s puno mara. On je dojedrio na istočnojadransku obalu u pratnji trinestorice kompetentnih suradnika, među kojima su vrsni teolozi, doktori crkvenog prava, apostolski notari i protonotari te dvojica plemića laika. ${ }^{35}$ Taj široki tim promatrao je konkretnu situaciju, prikupljao podatke, kritički ih vrednovao, te je tako apostolski pohoditelj mogao detaljnije upoznati konkretnu crkveno-religijsku i

\footnotetext{
${ }^{30}$ Agostino Valier, biskup Verone, rođen je 1553. godine u Veneciji, studirao je klasične jezike, pravo i teologiju u Rimu i Padovi gdje je 1554. godine promovirao. 1565. godine imenovan je veronskim biskupom gdje je, u duhu tridentskih smjernica, razvio osebujnu pastoralnu djelatnost. Valier je objavio više svojih djela na latinskom i talijanskom jeziku. Prije nego li je započeo vizitaciju biskupija u Južnoj Hrvatskoj dao je na hrvatski jezik prevesti i tiskati u Mletcima 1578. godine katekizam koji je osobno priredio za Veronsku biskupiju i obilazeći župe u Dalmaciji dijelio ga je besplatno župnicima. Poslije vizitacije Mletačke Dalmacije i Istre obišao je Chioggiu i Veneciju. Papa Grgur XIII. okitio ga je 12. prosinca 1583. godine kardinalskim purpurom, a kao pročelnik Kongregacije za kler imao je velik utjecaj. Valier je preminuo 1606. godine u Rimu. L. TACCHELLA - M. M. TACCHELLA, Il cardinal Agostino Valier; Elisabetta PATRIZI, Personalità ed educazione. L'episcopato di Agostino Valier nella Verona post-tridentina (1565-1606), sv. 1: Vita e azione pastorale, sv. 2: Lettere, decreti, ordinamenti e scritti educativi, Milano, 2015.

31 Usp. ovdje bilj. 3.

${ }^{32}$ AAV, Secr. Brev. Reg. 44, fol. 577 $-582^{\mathrm{v}}$.

33 AAV, Congr. Vescovi e Regolari, Registra Episc. 3, fol. 140v.

34 AAV, Congr. Vescovi e Regolari, Registra Episc. 3, fol. 141 ${ }^{\mathrm{v}}-142^{\mathrm{r}}$.

${ }^{35}$ Njihova imena donosi I. VITEZIĆ, str. 23; T. PERINČIĆ, »Prilog istraživanju«, str. 163.
} 
političko-gospodarsku situaciju u mletačkoj Dalmaciji. Kako bi se mogao lakše susresti s klercima, sazivao je zajedno s mjesnim biskupima dijecezanske sinode na kojima je nesmetano komunicirao s klerom i mogao u osobnom razgovoru bolje upoznati konkretnu situaciju svake pojedine biskupije. O svojim osobnim dojmovima i izvještajima svojih suradnika slao je Kongregaciji za biskupe i redovnike redovno izvješća u kojima kardinalu predstojniku Maffeju zorno oslikava teške gospodarske prilike i posvemašnju neimaštinu stanovništva na istočnojadranskoj obali. Vjernici ne mogu davati svećenicima desetinu pa su oni prisiljeni raditi svekolike poslove: oni koji žive na otocima i probalju bave se ribarenjem, a drugi zarađuju svoj svakodnevni kruh kao najamni radnici. Mahom ne nose kleričku odjeću, nego se odjevaju kao i drugi vjernici. ${ }^{36}$

Budući da se za povjerenu misiju pomno pripremio, nije biskup Valier odugovlačio s putovanjem u mletačku Dalmaciju. Iz Venecije je doplovio u Zadar i odatle je krenuo prema Kotoru, namjeravjući započeti svoj vizitacijski pohod na jugu i ploveći prema sjeveru obilaziti svaku pojedinu biskupiju. Zbog lošeg vremena zaustavio se na otoku Hvaru te je bio prisiljen započeti vizitaciju na tom otoku. ${ }^{37}$ Obišao je cijelu Hvarsku biskupiju gdje je u katedrali 9. veljače 1579 . godine održao dijecezansku sinodu.$^{38} \mathrm{Za}$ vrijeme svete mise na kojoj je sudjelovao mjesni biskup i kler, održao je Valier propovijed u kojoj je naglasio razloge svojeg vizitacijskog pohoda potičući sve na obdržavanje neophodne crkvene stege. Poslije nje uputio se prema Jugu, ali se i ovaj put zbog lošeg vremena zaustavio 17. veljače na Korčuli, koju je vizitriao. ${ }^{39}$ Kada se vrijeme poboljšalo, mogao je obići Kotorsku i Budvansku biskupiju. ${ }^{40}$ Ploveći prema sjeveru, dojedrio je biskup Valier sa svojim pratiteljima na otok Korčulu. Tu je u dogovoru sa svojim najbližim suradnicima zaključio da Lorenzo Arbertini i Ascanio Randoli putuju na Hvar, gdje su se zadržali jedanaest dana, a apostolski pohoditelj uputio se prema sjeveru, obilazeći Splitsku crkvu gdje je 31. ožujka 1579. godine u katedrali održao s nadbiskupom i klerom dijecezansku sinodu. ${ }^{41}$ Albertini i Randoli obišli su još Brač, Šoltu i Drvenik te su se uputili prema Omišu, gdje su se susreli susreli s Valierom. On je u njihovoj pratnji nastavio vizitaciju Trogirske crkve, gdje je 10. travnja 1579. godine pod njegovim predsjedanjem zasjedala dijecezanska sinoda. ${ }^{42}$

Tijekom posljednjih dvaju travanjskih tjedana obišao je biskup Valier Šibensku biskupiju i tu je 27. travnja održao dijecezansku sinodu na kojoj su uz njega i mjesnog biskupa sudjelovala još trideset i četiri svećenika. ${ }^{43}$ Odatle se uputio u Zadar, gdje je stigao 1. svibnja, i tu se zadržao do 23. svibnja 1579. godine. U tom razdoblju obilazio je osobno pojedine gradske crkve, a njegovi suradnici obilazili su pojedine izvangradske župe (kopnene i one na otocima) koje su pripadale mletačkom dominiju. Uz njih je poslao suradnike u Nin, koji

\footnotetext{
${ }^{36}$ Njegova pisma danas se čuvaju u AAV, Misc. Arm. VII, 139.

${ }^{37}$ Pojedinosti donosi D. DOMANČIĆ, »Valijerova vizitacija na otku Hvaru i Visu«, str. 37-58.

${ }^{38}$ Usp. V. BLAŽEVIĆ, Concilia et synodi, str. 81; ISTI, Crkveni partikularni sabori, str. 150.

39 Usp. A. J. MATANIĆ, »Prilog povijesti Korčulanske biskupije. Apostolska vizitacija nekadašnje Korčulanske biskupije godine 1579, s posebnim osvrtom na župu Blato«, str. 392-397.

40 Usp. Jadranka NERALIĆ, »Apostolske vizitacije u fondu Congregazione vescovi e regolari Vatikanskoga tajnog arhiva«, Tridentska baština, str. 175-191, ovdje str. 187-188.

41 V. Blažević, Concilia et synodi, str. 80; Isti, Crkveni partikularni sabori, str. 158.

42 V. Blažević, Concilia et synodi, str. 81; Istı, Crkveni partikularni sabori, str. 159.

${ }^{43}$ Podatak donosi V. BLAŽEVIĆ, Concilia et synodi, str. 81; IsTI, Crkveni partikularni sabori, str. 159.
} 
su obilazili Ninsku biskupiju. ${ }^{44}$ Poslije je vizitator obišao Krčku i Rapsku biskupiju, gdje je 1. lipnja 1579. godine sazvao dijecezansku sinodu. ${ }^{45}$ Prije svojeg odlaska biskup Valier obišao je još i Osorsku biskupiju, ali u njoj nije više održao dijecezansku sinodu.

Sve dijecezanske sinode u mletačkoj Dalmaciji na kojima je biskup Valier sudjelovao pokazuju istu shemu. Započinjale su svetom misom i prigodnim govorom apostolskog vizitatora, gdje je naveo razloge svojeg dolaska. Poslije se o mnogočemu raspravljalo, a ponajviše su se prisutni klerici podučavali u kršćanskom ćudoređu i nauku. Vizitator je opominjao kler, ukazivao je na neophodnu njihovu ćudorednost, obvezno nošenje kleričke odjeće, tonzure i zabranu nošenja oružja jer ono nije spojivo s njihovim kleričkim pozivom. Oni svećenici koji žive u priležništvu moraju, otpustiti svoje priležnice, strogo im se zabranjuje imati u župnoj kući neku ženu, a ukoliko u domaćinstvu nekog klerika stanuje ženska osoba, tada samo uz odobrenje mjesnog ordinarija. Upravo su se sve spomenute teme našle na dnevnom redu saborskih zasjedanja, što pokazuje da je apostolski pohoditelj sadržajno pripremao pokrajinski sabor u Zadru obilazeći pojedine biskupije. Sudionici sabora su ih trebali provoditi u povjerenim biskupijama. Osobito su biskupi, prema odredbama Tridentskog sabora, trebali rezidirati u povjerenim biskupijama i osobno podučavati kler i puk propovijedajući kršćanski nauk.

Preduvjet je bio poznavanje hrvatskog jezika, koji vizitator naziva ,ilirski”. Biskup Valier, uvidjevši u tom kratkom razdoblju, od svega nekoliko mjeseci, koliko je važno razumijevanje i dobro poznavanje jezika kojim se služe obični vjernici, zahtijevao je od svih nadbiskupa, biskupa i drugih visokih crkvenih dostojanstvenika, koji su odreda Mlečani i nisu poznavali hrvatski jezik, da u znak poštovanja prema narodu koji im je povjeren trebaju naučiti njihov svakodnevni jezik te da kao dobri pastiri trebaju sabranom puku na njihovu materinskom jeziku propovijedati i podučavati ga u kršćanskim krepostima. Istu je zapovijed izdao i redovnicima koji su dolazili iz susjedne Italije, a nisu dovoljno poznavali hrvatski jezik. ${ }^{46}$

Valierov pokušaj loma jezične barijere između običnog klera i „običnih” vjernika na jednoj strani te visoke crkvene hijerarhije na drugoj strani nije urodio plodom jer velik dio visokih crkvenih dostojanstvenika nije prihvaćao njegove poticaje. Takva se negativna ocjena odnosi na one dostojanstvenike koji nisu, baš uvijek, marili za situaciju u Dalmaciji niti su htjeli učiti jezik kojim vjernici svakodnevno komuniciraju. Jedan dio njih pokušavao je okrenuti leđa mletačkoj Dalmaciji i zadobiti unosnije službe u rodnoj Italiji. Apostolski pohoditelj je to očigledno zapazio, a uz nedostatak dobro izobraženih svećenika navodi u pismu od 5. svibnja 1580. godine da velik problem predstavljaju upravo nadbiskupi i biskupi, koji uglavnom osobno ne borave u povjerenim biskupija-

\footnotetext{
${ }^{44}$ Pojedinosti donosi Amos Rube Filipi u dvijema studijama koje su navedene ovdje u bilj. 9.

${ }^{45}$ AAV, cod. 413A, Visitatio Apost. Dalmatiae, Visit. Arbensis, fol. 2v; V. BLAŽEVIĆ, Concilia et synodi, str. 81-82; ISTI, Crkveni partikularni sabori, str. 159-160.

${ }^{46}$ Usp. D. FARLATI, Illyricum sacrum, sv. 5, str. 132; Luka JELIĆ, Fontes historici liturgiae glagolito-romanae a XIII ad XIX saeculum, d. saec. XVI, Veglae, 1906., str. 34; Jerko FUĆAK, Šest stoljeća hrvatskoga lekcionara u sklopu jedanaest stoljeća hrvatskoga glagoljaštva, Zagreb, 1975., str. 101, bilj. 117; S. KRASIĆ, Počelo je u Rimu, str. 149.
} 
ma, nego se oslanjaju na vikare i kanonički zbor, koji obavljaju svakodnevne crkvene poslove. ${ }^{47}$

\section{Sudionici sabora}

Pokrajinski sabor južnohrvatskih biskupija sazvao je apostolski pohoditelj Valier negdje dan ili dva prije 20. svibnja 1579. godine, jer je sabor upravo na taj dan dopisom poslanim iz Zadra zamolio Kongregaciju za biskupe i redovnike da materijalno pomogne tiskanje katekizma na hrvatskom jeziku. ${ }^{48}$ Vizitator je odabrao upravo taj grad za mjesto saborskih zasjedanja zbog toga što je najjače i najsigurnije mletačko uporište na drugoj strani Jadrana te su biskupi iz drugih biskupija mogli nesmetano i bez velike opasnosti morskim putem stići u Zadar. Mjesto njegova zasjedanja je benediktinski samostan sv. Krševana, koji je još papa Eugen IV. (1431. - 1447) pretvorio u komendu povjerivši je svojem nećaku kardinalu Pietru Barbu, kasnije papa Pavao II. (1464. - 1471.). ${ }^{49} \mathrm{Uz}$ apostolskog pohoditelja sudjelovao je njegov domaćin nadbiskup Natale Venier $(1577 .-1588 \text {. })^{50}$ sa svojim sufraganima, biskupom Petrom Bembijem iz Krka (1564. - 1589. $)^{51}$ i biskupom osorskim Koriolanom Garzadorom (1575. - 1614.). ${ }^{52}$ Splitski nadbiskup i metropolit Alojzije Michaelis (1566. - 1579.) nije bio, najvjerojatnije zbog starosti, prisutan, nego ga je predstavljao nadbiskup koadjutor Ivan Dominik Malquoto, nazvan Foconio $(1577 .-1602 .)^{53}$ sa sufraganima Splitske metropolije, biskupom šibenskim Lukom Spingarolijem (1573. - 1589.), ${ }^{54}$ biskupom hvarskim Martinom II. de Martinisom (1574. - 1581. ${ }^{55}$ i biskupom

\footnotetext{
${ }^{47}$ Usp. AAV, Congr. Vescovi e Regolari, Registra epist. 5, fol. $47^{\mathrm{r}}$.

48 Podatak je pronašao u Vatikanskom arhivu Tonči TRSTENJAK, »Hrvatski katekizmi u razdoblju tridentske obnove XVI. stoljeća«, Obnovljeni život, br. 69, Zagreb, 2014., str. 339-353, ovdje str. 346, ponešto izmijenjeni tekst u: »Hrvatski katekizmi u razdoblju tridentske obnove u 16. stoljeću«, Tridentska baština, str. 267-282, ovdje str. 274.

49 Pojedinosti donosi Ivan OSTOJIĆ, Benediktinci u Hrvatskoj i ostalim našim krajevima, sv. 2: Benediktinci u Dalmaciji, Split, 1964., str. 49; E. PERIČIĆ, »Samostan Svetog Krševana kroz lik i djelovanje njegovih opata«, 1000. godina samostana sv. Krševana u Zadru. Prilozi sa znanstvenog skupa održanog 11. i 12. prosinca 1986. u Zadru, u povodu 1000. obljetnice samostana Svetog Krševana i 30. obljetnice filozofskog fakulteta u Zadru, Ivo PETRICIOLI (prir.), Zadar, 1990., str. 79-108, ovdje str. 105; Miroslav GRANIĆ, »Opatija sv. Krševana u komendi«, 1000 godina samostana sv. Krševana u Zadru, str. 153-162, ovdje str. 153-157.

${ }^{50}$ D. FARLATI, Illyricum sacrum, sv. 5, str. 131; C. F. BIANCHI, Zara cristiana, sv. 1, str. 62-63; Hierarchia catholica medii aevi sive summorum pontificum $S$. R. E. cardinalium ecclesiarum series, sv. 3: saeculum XVI, ab anno 1503 complectens, Ludovicus SCHMITZ-KALLENBERG (prir.), Monasterii, 1923., str. 215; Josip BUTURAC - Antun IVANDIJA, Povijest Katoličke crkve među Hrvatima, Zagreb, 1973., str. 345; Zvjezdan STRIKA, »,,Catalogus episcoporum et archiepiscoporum urbis Iadertinae” arhiđakona Valerija Pontea«, str. 176; IsTI, »Zadarske sinode«, str. 84.

${ }^{51}$ Hierarchia catholica, sv. 3, str. 328; J. BUTURAC - A. IVANDIJA, Povijest Katoličke crkve, str. 340.

${ }_{52}$ Hierarchia catholica, sv. 3, str. 92; J. BUTURAC - A. IVANDIJA, Povijest Katoličke crkve, str. 341.

${ }_{53}$ Hierarchia catholica, sv. 3, str. 303; sv. 4, str. 320; J. BUTURAC - A. IvANDIJA, Povijest Katoličke crkve, str. 349.

${ }^{54}$ Hierarchia catholica, sv. 3, str. 299; J. BUTURAC - A. IVANDIJA, Povijest Katoličke crkve, str. 344; Krsto STOŠIĆ, Galerija uglednih Šibenčana, Šibenik, 1936., str. 76; Lovorka ČORALIĆ, »Dominikanski samostan u Zadru u oporukama zadarskih plemića (XVI-XVIII. st.)«, Croatica christiana periodica, god. 18, br. 34, Zagreb, 1994., str. 199-208, ovdje str. 202-203, bilj. 9; Josip BARBARIć, »Šibenik, Šibenska biskupija, šibenski biskupi«, Sedam stoljeća Šibenske biskupije. Zbornik radova sa znanstvenog skupa Šibenska biskupija od 1298. do 1998. Šibenik, 22. do 26. rujna 1998, Josip ĆUZELA - Vicko KAPITANOVIĆ i. dr. (prir.), Šibenik, 2001., str. 79-164, ovdje str. 128-130.

${ }^{55}$ Hierarchia catholica, sv. 3, str. 273; J. BUTURAC - A. IVANDIJA, Povijest Katoličke crkve, str. 350.
} 
ninskim Petrom Cedolinom (Cedulinom) (1577. - 1581.) koji je zbog nedostatka prikladnog smještaja boravio u sigurnijem Zadru. ${ }^{56}$ Biskup kotorski Franjo Zapan (1578. - 1581.) bio je jedini predstavnik episkopata Dubrovačke metropolije. ${ }^{57}$

Jedan dio rezidencijalnih biskupa bio je odsutan i nije sudjelovao na saboru: biskup rapski Blaž Sidineo (1567. - 1583.) ${ }^{58}$, zbog teške bolesti, biskup trogirski Ante Guido (1574. - 1604. $)^{59}$, zauzet nekim neodgodivim obvezama u Veneciji, biskup korčulanski Augustin Kvinčić (1573. - 1605.) ${ }^{60}$ i biskup Daniel Vokacije iz Duvna (1551. - 1590.), ${ }^{61}$ koji je administrator Makarske biskupije. ${ }^{62}$ Nadbiskup dubrovački Vincent Porticus (1575. 1579. $)^{63}$ nije sudjelovao na saboru, a možda nije bio ni pozvan jer je apostolski pohoditelj imao vizitacijski mandat samo za ono područje koji je pod mletačkom upravom. Isto tako je biskup bosanski Ante Polus de Matthaeis (1573. - 1588.) bio odsutan. ${ }^{64} \mathrm{Za}$ biskupa senjskog Grgura (1577. - 1584. $)^{65}$ i biskupa kninskog Zahariju Mossoczy (1573. - 1584.) ${ }^{66}$ nije poznato jesu li bili pozvani na sabor ili nisu.

Odgovaraju li razlozi nesudjelovanja na saboru povijesnim činjenicama ili ne, teško se može iz današnje perspektive prosuditi. Ukoliko se pogleda stvarni broj sudionika i nesudionika, dolazi se skoro do istog omjera nazočnih i odsutnih biskupa pa i ta činjenica govori u prilog neodržavanja biskupske rezidencije u pojedinim biskupijskim središtima, kako je to zapazio biskup Valier, i u svojem je pismu 5. svibnja 1580. godine izričito ukazao na takvu praksu u mletačkoj Dalmaciji. ${ }^{67}$ Pojedinici su samo komendatorski biskupi, najčešće u službi Rimske kurije ili mletačke vlade, te nisu osobno stanovali u središtima biskupija, nego su iz njih samo primali svoje komendatorske prihode. Južnohrvatska biskupska sjedišta i benediktinske opatije služile su još od sredine 15. stoljeća kao izvor unosnih prebendi sinovima mletačkih patricija za njihov lagodniji život u Vječnom Gradu

\footnotetext{
${ }^{56}$ D. FARLATI, Illyricum sacrum, sv. 4, str. 227; Hierarchia catholica, sv. 3, str. 260; Adolf GOTTLOB, »Die lateinischen Kirchengemeinden in der Türkei und ihre Visitation durch Petrus Cedolini, Bischof von Nona, 1580-1581«, Historisches Jahrbuch, sv. 8, München, 1885., str. 42-72. Biskup Cedolini je 1581. godine premješten na Hvar i tu je vršio službu sve do 1631. godine. Lovorka ČORALIĆ, »Prilog poznavanju života hvarskog biskupa Petra Cedulina«, Croatica Christiana Periodica, god. 15, br, 27, Zagreb, 1991., str. 129-135.

57 Hierarchia catholica, sv. 3, str. 160.

${ }^{58}$ Hierarchia catholica, sv. 3, str. 115; Lovorka ČORALIĆ, »Prilog životopisu rapskog biskupa Blaža Sidinea (1567. - 1583.)«, Radovi Zavoda za povijesne znanosti HAZU u Zadru, sv. 45, Zagreb - Zadar, 2003., str. 137-151, ovdje str. 139 .

${ }^{59}$ Hierarchia catholica, sv. 3, str. 316.

${ }^{60}$ Daniele FARLATI - Jacobo COLETI, Illricum sacrum, sv. 6, Venetiis, 1800., str. 396; Božo BANIČEVIĆ, »Korčulanska biskupija (1300. - 1830.); prilog poznavanju povijesti Korčulanske biskupije u povodu 700. obljetnice njezina utemljenja«, Crkva u svijetu, br. 35, Split, 2003., str. 123-137; Ivan ARMANDA, »Korčulanski biskup Augustin Kvincije u crkvenim i društveno-političkim zbivanjima svoga doba«, Povijesni prilozi, br. 43, Zagreb, 2012., str. 59-79, ovdje str. 66

${ }^{61}$ Hierarchia catholica, sv. 3, str. 189; J. BUTURAC - A. IVANDIJA, str. 337, a s njima i M. VIDOVIĆ, str. 559. smatraju da je biskup Daniel predvodio biskupiju do 1575. godine, što očigledno ne odgovara povjesnoj stvarnosti.

${ }^{62}$ Hierarchia catholica, sv. 3, str. 189; M. VIDOVIĆ, str. 549 ne spominje biskupa Daniela kao apostolskog administratora Makarske biskupije.

${ }^{63}$ Hierarchia catholica, sv. 3, str. 281.

${ }^{64}$ Isto, str. 138.

65 Isto, str. 299.

66 Isto, str. 314.

${ }^{67}$ Usp. ovdje bilj. 47.
} 
ili na mletačkim lagunama. Naravno, pape su prije Tridenta svesrdno podržavali komendatorski sistem i postojeću komendatorsku praksu jer se na taj način nisu trebali brinuti za materijalnu sigurnost svojih namještenika ili svojih bližih rođaka. Nasuprot tomu, krajevni sabor poduzeo je neophodnu obnovu crkvene prakse na istočnojadranskoj obali i donio devet konkretnih konstitucija koje su sadržajno prožete reformnim duhom Tridentinskog sabora. ${ }^{68}$ One ukazuju na konkretnu situaciju Crkve u mletačkoj Dalmaciji, pritješnjenoj otomanskim susjedstvom i kako zaključuje Farlati, "posvuda se vidi Augustinova pobožnost, učenost, razboritost, i snažno gorljivo nastojanje oko obnove crkvene discipline, povećanja božanske slave, i posvemašnje brige oko spasenja duša « ${ }^{69}$.

\section{Saborski zaključci}

Sabor je u duhu posttridentske obnove započeo s konstitucijom $O$ onome što spada na biskupe: biskup je trebao postati pastir povjerene biskupije i stoga se naglašava obveza njihove osobne rezidencije u njezinu sjedištu. ${ }^{70}$ Poslije Tridentskog sabora taj smjer je naglašavala rimska administracija, a i sama ga je samo djelomično provodila u praksu. Tek je papa Grgur XIII. provodio saborski zaključak i u konzistoriju 17. listopada 1572. godine sažeo ga je sljedećim riječima: »Tko osobno ne može ili nije sposoban održavati rezidenciju treba se odreći povjerene biskupije . $^{71}$ To je jasan glas, a upravo je taj papa poslao biskupa Valiera na istočnojadransku obalu s izričitom zadaćom neka vizitira cijelu pokrajinu i pripomogne vjerskoj obnovi u siromašnim biskupijama koje će posjetiti. Krajevni sabor se u tom razdoblju pokazao se prikladnim sredstvom za obnovu biskupske službe i djelotvornije kontrole njihove rezidencije u povjerenim biskupijama, tako da su oni stvarno morali obitavati u njima, a ne, kako je to bio prije običaj, samo primati svoja komendatorska podavanja, a dugoročno obitavati u Rimu ili daleko lagodnijoj Veneciji.

Istodobno se određuje neka svi nadbiskupi i biskupi, kanonici i svećenici prepišu jedan primjerak koncilskih konstitucija te ih nedjeljom poslije svete mise tumače sabranom puku. Ukoliko osobno ne znaju ilirski (čitaj: hrvatski) jezik, neka ga nastoje što prije naučiti kako bi mogli što bolje ispuniti povjerenu zadaću. ${ }^{72}$ Upravo taj poticaj, koji je trebao prebroditi jezičnu barijeru između visokog klera na jednoj strani i župnika glagoljaša s vjernicima laicima na drugoj strani, bilo je na istočnojadranskom području pod mletačkom upravom

${ }^{68}$ Usp. Hubert JEDIN, »Der Kampf um die bischöfliche Residenzpflicht 1562/63«, Concilium Tridentinum, str. 408-431.

${ }^{69}$ D. FARLATI, Illyricum sacrum, sv. 5, str. 131; V. BLAŽEVIĆ, Crkveni partikularni sabori, str. 106.

${ }^{70}$ De iis, quae ad episcopos pertinent. D. FARLATI, Illyricum sacrum, sv. 5, str. 132-134; Z. STRIKA, »Zadarske sinode $\ll$, str. 85 .

${ }^{71}$ Ludwig Freiherr von PASTOR, Geschichte der Päpste seit dem Ausgang des Mittelalters, sv. 9: Geschichte der Päpste im Zeitalter der katholischen Reformation und Restauration: Gregor XIII. (1572-1585), fünfte bis siebte, unveränderte Auflage, Freiburg im Breisgau, 1925., str. 49. Nešto izmijenjeni prijevod teksta donosi S. KRASIĆ, Počelo je u Rimu, str. 155. Boravak pojedinih biskupa izvan povjerene biskupije imao je djelomično i gospodarsko-novčane razloge. Njihovi prihodi su se znatno razlikovali, dok je prema izvješću apostolskog vizitatora Valiera materijalno bio najbolje opskrbljen hvarski biskup s 800 dukata i njegov zadarski kolega s istom sumom, dotle je njegov kolega iz Nina imao godišnje prhode od svega 100-130 dukata. Najslabije je ipak bio materijalno osiguran biskup Kotora, koji je imao godišnje prihode od svega 80 dukata. S. KRASIĆ, Počelo je u Rimu, str. 156.

72 D. FARLATI, Illyricum sacrum, sv. 5, str. 132. 
jako teško provesti. Razlog je njihovo nepoznavanje latinskog i talijanskog jezika, a nad/ biskupi nisu razumjeli hrvatski, pa se danas mora pretpostaviti da su za svećenike glagoljaše postojali hrvatski prijevodi pojedinih koncilskih odredaba, barem onih koji se odnose na kleričku stegu, slavljenje svete mise i podjeljivanje pojedinih sakramenata.

$\mathrm{Na}$ samom početku sabora prisutni su biskupi jedinstveni u ocjeni trenutačne situacije da je za što bolju intelektualnu izobrazbu svećenika po odredbi Tridentskog sabora nužno osnivanje sjemeništa kako ne bi Crkvu neznanje svećenstva sramotilo više od njihova malenog broja. Svaka biskupija za sebe nije mogla zbog gospodarskih neprilika osnovati takvu instituciju, a sabor je smatrao potrebnim da se $u$ Dalmaciji trebaju podignuti barem dvije takve institucije, i to jedna u Zadru, a druga u Splitu. U njima bi se moglo podučavati godišnje najmanje 40 klerika, te bi za njihovo školovanje trebalo namiriti novčanu svotu od 600 dukata. Jedan dio potrebnih sredstava bi se mogao podmirivati ujedinjavanjem nekih crkvenih nadarbina u pojedinim biskupijama, a drugi dio potporom Svete Stolice. ${ }^{73}$ Za tadašnje prilike u mletačkoj Dalmaciji to je ogromna svota novca koju se moglo godišnje jako teško iz crkvenih nadarbina namiriti, ${ }^{74}$ pa sabrani biskupi prepuštaju Rimskoj kuriji neka ona sama odluči koje se mjere trebaju poduzeti: je li prikladnije otvoriti sjemenište u Dalmaciji ili primiti studente na neko talijansko sveučilište. Ukoliko bi se u Rimu držalo da je jednu takvu instituciju u Dalmaciji jako teško uzdržavati, neka se tada barem iz svake biskupije pošalju po četiri studenta na studij u rimski Collegium Germanicum. Sabor ipak smatra najadekvatnijim rješenjem ako bi se u Rimu osnovao dalmatinski zavod (Collegium Dalmaticum) za studente iz istočnojadranskih biskupija jer bi se time mogao jako brzo nadoknaditi nedostatak visoko izobraženih klerika u svim biskupijama. Uz te preventivne mjere trebao bi u nekom dalmatinskom gradu osnovati barem jedan isusovački kolegij za školovanje svjetovne mladeži i onih koji se pripremaju za duhovnu službu. ${ }^{75}$

Taj koncilski poticaj ipak nije zbog razno-raznih razloga (ponajviše zbog nedostatka materijalnih sredstava) proveden, dapače dva najveća centra mletačke vlasti u Dalmaciji, Zadar i Split, za taj pothvat nisu imali nikakvih materijalnih uvjeta, a druge biskupije još manje. Jedini izuzetak je Dubrovačka crkva. Gradnja isusovačkog kolegija započeta je u Dubrovniku tek 1662. godine, a nedovršenu zgradu razorio je veliki potres 6 . travnja 1667. godine tako da je njegova gradnja mogla biti nastavljena tek nekoliko godina kasnije, a dovršena je tek za rektora Rafe Tomaševića, koji je preminuo 1696. godine. $^{76}$

${ }^{73}$ D. FARLATI, Illyricum sacrum, sv. 5, str. 132; Šime URLIĆ, Crtice iz dalmatinskog školstva od dolaska Hrvata do g. 1814., I. dio, Zadar, 1919., str. 37; Stjepan KRASIĆ, Generalno učilište, str. 236-237; Z. STRIKA, »Zadarske sinode «, str. 85.

${ }^{74}$ U Dalmaciji nije bilo moguće podići sjemenište, pokrajina je graničila s otomanskim zaleđem i siromaštvo se osjećalo na svakom koraku. Mletačka vlada nije se baš previše brinula za kulturnu izobrazbu i prosperitet domaćeg stanovništva, što je još dodatno otežavalo situaciju. Slavko KOVAČIĆ, »Katedralne škole u Dalmaciji pod mletačkom vlašću od konca 16. do početka 19. stoljeća prema biskupskim izvještajima Svetoj Stolici«, Croatica christiana periodica, god. 15, br. 27, Zagreb, 1991., str. 59-87; S. KRASIĆ, Počelo je u Rimu, str. 161-164.

${ }^{75}$ D. FARLATI, Illyricum sacrum, sv. 5, str. 132; Josip JURIĆ, »Ilirski kolegij u Loretu 1580-1860«, Vrela $i$ prinosi. Zbornik za povijest isusovačkoga reda u hrvatskim krajevima, br. 13, Zagreb, 1982., str. 25-26; S. KRASIĆ, Počelo je u Rimu, str. 164.

${ }^{76}$ Usp. Miroslav VANINO, Isusovci i Hrvatski narod, sv. 2: kolegiji dubrovački, riječki, varaždinski i požeški, Zagreb, 1987., str. 55-66. 
Svim koncilskim sudionicima jasno je da takav pothvat zahtijeva dugoročniju pripremu, pa stoga predlažu Rimskoj kuriji neka se iz Dalmacije u Rim, Bolognu ili Perugiu primi barem jedan ili dva klerika iz svake pojedine biskupije koji će na pravnim fakultetima studirati crkveno pravo najmanje pet godina. ${ }^{77}$ Takva mjera mogla bi kratkoročno nadoknaditi veliku nestašicu crkvenih pravnika i dobro izobraženih klerika u drugim teološkim disciplinama koju je najviše prouzrokovala otomanska pritješnjenost, bijeda, neimaština, nedostatak sjemeništa tridentskog tipa, a jednim velikim dijelom i odnos mletačkih vlasti prema Crkvi i njenim institucijama u Dalmaciji.

Apostolski pohoditelj Valier, koji je objektivan promatrač prilika na istočnojadranskoj obali, donosi u svojem izvješću zanimljivo zapažanje u kojem javlja Svetoj Stolici da su svećenici glagoljaši bolje izobraženi negoli su to njihove kolege „latinaši”, tj. oni svećenici koji slave službu Božju na latinskom jeziku. Oni su i na višoj ćudorednoj razini negoli njihove kolege „latinaši” u gradskim središtima, oni su daleko manje kršili crkvenu stegu, osobito zakon o celibatu, negoli svećenici u gradovima. ${ }^{78}$ C̆ak su bolje opskrbljeni liturgijskim knjigama negoli njihove kolege "latinaši”, oni su posjedovali misale, brevijare, župničke priručnike i druge važne knjige na svojem narodnom hrvatskom jeziku. ${ }^{79}$ Na prvi pogled takva razlika sugerira podjelu dalmatinskog klera (osobito onog zadarskog), ali je ona u konkretnoj stvarnosti bila daleko neznatnija negoli to dostupna vrela i kasnija literatura sugeriraju jer je najveći dio svećenika slavio liturgijske obrede isključivo hrvatskim jezikom, dok se drugi dio služio latinskim i hrvatskim jezikom. Za njihovu što bolju intelektualnu i bogoslovnu izobrazbu određeno je neka se prevede na hrvatski jezik Summa theologica moralis dominikanca i kasnijeg firentinskog nadbiskupa Anto-

77 Usp. D. FARLATI, Illyricum sacrum, sv. 5, str. 132; I. VITEZIĆ, str. 41; S. KRASIĆ, Generalno učilište, str. 237; ISTI, Počelo je u Rimu, str. 164. Papa Grgur XIII. brzo je prihvatio molbu zadarskog koncila, određujući već 5. studenoga 1579. godine neka se nasuprot Zadru, u Loretu na trošak tamošnjeg svetišta otvori papinski iliriski zavod (Collegium Illyricum Lauretanum) za izobrazbu budućih svećenika iz Dalmacije, koji će se poslije uspješno završenih studija vraćati u svoje matične biskupije. Josip JURIĆ - Mijo KORADE, Iz arhiva građe o Iliriskom kolegiju u Loretu. Podatci o pitomcima Ilirskog kolegija u Loretu (1580-1658), Vrela $i$ prinosi, br. 13, Zagreb, 1982., str. 61-105; br. 14, Zagreb, 1983., str. 155-203.

${ }^{78} \mathrm{Na}$ taj podatak ukazuje Ivan Vitezić i osobito Amos Rube Filipi, koji su temeljito proučili Valierovo izvješće. Na navedenom mjestu Filipi donosi sljedeći podatak: pred apostolskim pohoditeljem se od Kotora do Krka vodio 21 proces, od kojih se 20 odnosio na svećenike u gradskim centrima: od tih se 13 odnosili na kanonike, a od preostalih osam šest se odnosilo na gradski kler i samo jedan se odnosio na nekog seoskog svećenika glagoljaša. Iz tih podataka zaključuje Filipi da su svećenici glagoljaši na visokoj ćudorednoj razini i da ih je bilo puno više nego li svećenika u gradovima. Amos Rube FILIPI, »Popovi glagoljaši na visini svog poziva«, Vjesnik Zadarske Nadbiskupije, br. 7, Zadar, 1964., str. 141-148, ovdje str. 144; ISTI, »Biogradsko-vransko područje u doba mletačko-turskih ratova«, Radovi Instituta JAZU u Zadru, br. 19, Zadar, 1972., str. 405-498, ovdje str. 489-490.

79 Valierov pomoćnik dr. Ascanius Randolus (župnik u Caldieru u Veronskoj biskupiji) je poslije obilaska nekih otočkih župa pribilježio sljedeće izvješće: Omnes sacerdotes harum insularum sunt penitus ignari linguae latinae nec admodum callent doctrinam christianam. Celebrant omnes secundum ritum latinum, sed in lingua Illyrica in cuius idyomate (!) et caractere habent impressa (!) Breviaria, Missalia, Manipulos curatorum, Quadragesimale et alios huius notare libros. A. R. FILIPI, »Popovi glagoljaši«, str. 147; S. KRASIĆ, Generalno učilište, str. 236. Apostolski pohoditelj općenito govori o svećenstvu u južnohrvatskim biskupijama da oni, premda ne poznaju latinski jezik, u crkvenim znanostima su dovoljno izobraženi, svećenstvo po selima stvarno je siromašno, ali od reda na visokoj ćudorednoj razini. U tome je ono prednjačilo pred gradskim klerom, kako je to pokazao Bolonić na primjeru svećenika Krčke biskupije. Mihovil BOLONIĆ, »Profil krčkog glagoljaša u prošlosti«, Croatica christiana periodica, god. 4, br. 6, Zagreb, 1980., str. 96-115, ovdje str. 99. 
nina (1389. - 1459. $)^{80}$ ili pak koji drugi prikladni i prokušani bogoslovni priručnik. ${ }^{81}$ Taj podatak, kako navodi Stjepan Krasić, pokazuje »svijest o potrebi« neophodnih teoloških priručnika za što bolju izobrazbu svećenika glagoljaša i monahinja, »jer one nisu znale drugoga jezika osim materinskoga ${ }^{82}$. Prijevodi na hrvatski jezik su već duže vrijeme postojali, ali njihovo tiskanje je zahtijevalo velike financijske izdatke pa su svećenici glagoljaši i dalje vlastoručno prepisivali neopohodne knjige za svoju daljnju izobrazbu. Naravno, oni su ih prepisivali glagoljicom, pismom koje su svakodnevno upotrebljavali, a pojedini povjesničari su ih kasnije, upravo zbog toga, smatrali neukim i priprostim koji se ne bi razlikovali od običnih i neizobraženih dalmatinskih stanovnika. ${ }^{83}$ Takva ocjena njihove naobrazbe očigledno ne odgovara konkretnoj povijesnoj stvarnosti i nastala je pod utjecjem talijanske historiografije druge polovice 19 . stoljeća.

Naslanjajući se na zaključak 23. zasjedanja Tridentinskog koncila nalaže se dužnost rezidencije u sjedištu povjerene biskupije, naučavanju i interpretaciji kršćanske vjere te slavljenje nedjeljne mise u gradskoj prvostolnici: »nema veće nesreće nego što je nepoznavanje osnova kršćanske vjere, bez kojih nitko ne dolazi u nebesku domovinu ${ }^{84}$. Mjesni biskup trebao je postati ključna osoba svekolike crkvene prakse i po njemu su pojedine župe trebale postati centralna mjesta gdje se podučava kršćanski nauk. Kod slavljena svetih misâ mjesni biskupi trebaju držati propovijed sabranim vjernicima, a ako osobno ne znaju ,ilirski jezik”, da ga, za spasenje duša otkupljenih dragocjenom krvlju Kristovom, nastoje što prije naučiti. ${ }^{85} \mathrm{Na}$ pojedine svetkovine biskupi su trebali osobno podučavati narod prema Rimskom katekizmu u kršćanskom nauku i izabrati klerike koji će naizmjenično obavljati tu službu. ${ }^{86}$

Koncilski zaključak je, odmah na samom početku, naglasio osobitu brigu biskupa za vjernike koji se nalaze s druge strane granice, nalažući im redovnu vizitaciju onih župa koje se nalaze na teritoriju Otomanskog Carstva. Ninska biskupija imala je pod mletačkom vlašću samo tri župe, dok su druge smještene na teritoriju pod osmanskom vlašću. Zadarska nadbiskupija bila je u nešto boljem položaju, nekoliko priobalnih župa i one na otocima bile su pod mletačkom vlašću. Druge su uspjeli zauzeti Osmanlije, koji su bili nadomak samom Zadru, granica je bila Crno i Dračevac.

Sabor osobito naglašava pedagoško-odgojni rad. Biskupima se nadalje nalaže neka nadziru učitelje i neka se brinu o religijskom odgoju mladeži, tako da se ne bi širile iz zapadnoeuropskih zemalja razne hereze, jer mladi ljudi, često iz vlastitog neznanja, znaju zapasti u različita krivovjerja. Istodobno se obnavljaju odluke o redovnom održavanju

\footnotetext{
${ }^{80}$ Djelo je prvi put tiskano u Veneciji 1477., a drugi put 1740. godine.

${ }^{81}$ D. FARLATI, Illyricum sacrum, sv. 5, str. 136; Marijan STOJKOVIĆ, »Rimska papinska protureformacija u južnoslavenskim zemljama«, Nastavni vjesnik, br. 22, Zagreb, 1913., str. 181-200, ovdje 198; T. TRSTENJAK, »Hrvatski katekizmi«, str. 346, 274.

82 S. KRASIĆ, Počelo je u Rimu, str. 226.

${ }^{83}$ Usp. ovdje u bilj. 79 navedenu literaturu.

${ }^{84}$ Cum nulla sit maior miseria, quam ignorare rudimenta christianae religionis, sine quibus nemo ad patriam caelestiam pervenit. D. FARLATI, Illyricum sacrum, sv. 5, str. 133.

${ }^{85}$ De iis, quae ad episcopos pertinent. D. FARLATI, Illyricum sacrum, sv. 5, str. 132. Na navedenom mjestu glasi latinski orginal: ... inter missarum solemnia sermonem ad populum hebeant, linguam Illyricam, nisi eam norint, studant edifcere pro salute animarum pretioso Christi sanguine redemptarum.

${ }^{86}$ D. FARLATI, Illyricum sacrum, sv. 5, str. 132; Z. STRIKA, »Zadarske sinode«, str. 85.
} 
pokrajinskih sabora i biskupijskih sinoda: svake treće godine trebao je zasjedati krajevni koncili, a dijecezanska sinoda je u pojedinim biskupijama trebala zasjedati jednom godišnje. Kao prikladan termin njezina održavanja određeno je vrijeme poslije Uskrsa (negdje do svetkovine Duhova). ${ }^{87}$

Detaljnija analiza saborske odredbe koja se naslanja na zaključke Tridentskog sabora nije potrebna jer samo letimičan pogled na broj održanih metropolitanskih sabora i dijecezanskih sinoda pokazuje kako nad/biskupi nisu smatrali shodnim obdržavati doneseni zaključak. Na temelju uvida u konkretnu situaciju druge polovice 16. i tijekom 17. stoljeća, sabrani biskupi nisu provodili saborsku odredbu te se može pretpostaviti da je ona uvrštena u konstitucije po nalogu apostolskog vizitatora. ${ }^{88}$

Istodobno je koncilski zaključak pokušao zabraniti pojedinim biskupima, nadbiskupima i drugim visokim crkvenim prelatima neopravdana i nerazložna putovanja izvan povjerene biskupije, kako zbog njihove odsutnosti ne bi trpio pastoral. Upravo je provođenje te odluke bilo iznimno teško provesti u konkretnu crkvenu stvarnost. Pojedini biskupi nisu se na nju osvrtali jer je djelomično dalmatinski episkopat živio stalno ili pak duže vrijeme u susjednoj Italiji, a »tako se kaže o nekom zadarskom nadbiskupu, podrijetlom iz prekomorskih krajeva, da za vrijeme svoga nadbiskupovanja nije nikada vidio Zadra, svoje rezidencije ${ }^{89}$. Nije to bio samo jedan zadarski nadbiskup, nego je tijekom prve polovice 16. stoljeća to već postala uobičajena praksa. U drugim dalmatinskim biskupijama pod mletačkom vlašću slična je situacija, pa se danas mora pretpostaviti da je sadržaj saborske odredbe inicirao apostolski pohoditelj osobno i zasigurno je bilo prisutnih biskupa koji su se protivili tim koncilskim konstitucijama, ali je njihova reakcija ostala do danas nepoznata.

Kako je boravak u sjedištu povjerene biskupije vrijedio za pojedine biskupe tako je isto pravilo vrijedilo i za druge crkvene osobe. Naime, sabor posebno ističe dužnost boravka redovnika u njihovim zajednicama jer se život pojedinih redovnika nije poklapao s ciljevima i pravilima njihovih redova. Redovnici su često iz različitih dalmatinskih samostana

${ }^{87}$ Quolibet triennio concilium provinciale fiat, ut Concilii Tridentini decreto sancitum est, quod non incommode fieri poterit, cum magna sit locorum propinquitas et admodum commoda navigatio, fiatque eo tempore, quod archiepiscopus commodius iudicaverit, in quo concilio novae, si necesse fuerit, constitutiones proponantur, et de observatione harum agatur, atque illic sese invicem episcopi consolentur, et in arte pascendarum animarum, quae omnium difficillima est, se invicem instruant. Quod si archiepiscopi hac in parte officio suo defuerint, antiquior suffraganeus residens possit concilium convocare.

Convocet unusquisque episcopus propriae ecclesiae synodum singulis annis post sanctissimae reusrectionis D. N. J. C. dies, quam unius diei spatio poterit absolvere; ibique examinatores et iudices iuxta formam Concilii Tridentini constituat. D. FARLATI, Illyricum sacrum, sv. 5, str. 132. Usp. Također: V. BLAŽEVIĆ, Concilia et synodi, str. 52; ISTI, Crkveni partikularni sabori, str. 106; Z. STRIKA, »Zadarske sinode«, str. 85 .

${ }^{88}$ Poslije 1579. godine nije u Zadru održan niti jedan jedini metropolitanski sabor, dok je u Splitu održan samo jedan 1587. godine. V. BLAŽEVIĆ, Concilia et synodi, str. 54; ISTI, Crkveni partikularni sabori, str. $107-108$.

89 A. R. FILIPI, »Samostan i crkva sv. Marije u Zadru«, str. 232, pozivajući se na rad I. VITEZIĆA, str. 9. Konstatacija Filipija ne predstavlja iznimnu novost, već je nadbiskup Matej Vallaresso (1450.-1494.) češće i poduže vrijeme boravio izvan Zadra, a njegovi nasljednici sve do nadbiskupa Callinija nisu rezidirali u centru nadbiskupije nego su samo sporadično svraćali u Zadar. Oni su najvećim dijelom visoki namještenici Rimske kurije i samo su primali svoja komendatorska podavanja. Da se takva situacija negativno odrazila na Zadarsku crkvu i pastoralni rad razumije se samo od sebe i nisu potrebna detaljnija objašnjenja. 
napuštali samostan da bi postajali privatni učitelji gramatike. ${ }^{90}$ Takav »zločesti običaj«, kako ga izričito oslovljava saborska odredba, trebao bi se odmah dokinuti. Predvoditeljima redovničkih zajednica nalaže se neka nastoje spriječiti takvo „bježanje” iz njihovih zajednica ${ }^{91}$ Namjera je bila iskrena i u duhu obnove redovničkog zajedništva, koje se nije moglo nikako zaobići, ali njihov pokušaj nije imao baš velikog uspjeha. Zadarski nadbiskup Oktavijan Garzadoro (1624. - 1639.), kao apostolski pohoditelj pedesetak godina kasnije napominje u svojem izvješću rimskoj administraciji da se uz mnoga druga zla po dalmatinskim Crkvama i samostanskim zajednicama uvriježilo neodržavanje crkvene stege. ${ }^{92}$

Uz te poticaje obnove kršćanskog života u mletačkoj Dalmaciji ukazuje koncilski zaključak na predstave i skazanja koja su omiljena pobožna literatura na istočnojadranskoj obali. U Zadru su se one redovno izvodile na hrvatskom jeziku u danas porušenoj crkvi sv. Silvestra. ${ }^{93}$ Apostolski vizitator, izričito preko sabora, zabranjuje predstave s religijskim sadržajem i to zbog toga jer đavao i s dobrim djelima znade iskvariti pobožne duše, kako se to često događalo kod scenskog prikazivanja muke našeg Gospodina Isusa Krista ili života pojedinih svetaca. Poslije takvih i sličnih predstava nastajale su većinom svađe i sukobi među prisutnom publikom, jedni su odobravali sadržaj, dok su ga drugi ismijavali. $\mathrm{Na}$ taj se način, smatrao je apostolski pohoditelj, svete stvari profano tretiraju i katkada se prisutne osobe nedolično odnose prema njima, ismijavaju njihov sadržaj, pa biskupi trebaju takva prikazanja u svim crkvama zabranjivati. ${ }^{94}$ Ta zabrana se očigledno nije odnosila na ceremoniju obreda golubice (la ceremonia della colomba) koja se izvodila najprije u katedrali sv. Stošije, a zatim i po drugim gradskim crkvama u predvečerje blagdana Bogojavljenja (Vodokršća) poslije blagoslova vode. O njezinu održavanju i pokušaju zabrane nadbiskupa Teodora Balbija (1646. - 1669.) iz 1669. godine izvještava detaljnije zadarski arhiđakon Ivan Tanzlingher Zanotti (1651. - 1732.). ${ }^{95}$

\footnotetext{
${ }^{90}$ Na ovom mjestu ukazujem samo na primjer dominikanca Augustina Pridojevića koji je stigao u Šibenik iz zadarskog dominikanskog samostana početkom 1570. godina. On je preuzeo mjesto učitelja u školi i brinuo se o orguljama u katedrali sv. Jakova. Ta činjenica ne bi bila osobita da on nije živio izvan dominikanskog samostana u iznajmljenoj kući zajedno s jednom ženom. Šibenčani su ga optužili pred apostolskim pohoditeljem. Sud ga je osudio izgonstvom iz Šibenika i biskupije, nalažući mu neka se vrati u zadarski dominikanski samostan.

${ }^{91}$ D. FARLATI, Illyricum sacrum, sv. 5, str. 133; Tomo MATIĆ, Iz hrvatske književne baštine, Zagreb - Slavonska Požega, 1970., str. 116-117.

92 ... depravatio disciplinae ecclesiaticae et monachalis, ... D. FARLATI, Illyricum sacrum, sv. 5, str. 159; T. MATIĆ, Iz hrvatske književne baštine, str. 116-117.

${ }^{93}$ U crkvi sv. Silvestra bratovština bičevalaca održavala je redovno svoju skupštinu. Budući da je ona porušena, bratovština se preselila 1541. godine u crkvu sv. Tome. Vlade CVITANOVIĆ, "Bratovštine grada Zadra«, Zadar: geografija - ekonomija - saobraćaj-povijest - kultura: zbornik, Zagreb, 1964., str. 457-470, ovdje str. 462-463.

${ }^{94}$ Usp. D. FARLATI, Illyricum sacrum, sv. 5, str. 134; Ante M. STRGAČIĆ, »Zadranin Šime Vitasović i kulturno-povijesno značenje njegova djela«, Radovi Instituta JAZU u Zadru, br. 2, Zagreb, 1955., str. 47-78, ovdje str. 62.

95 Usp. I. TANZLINGHER ZANOTTI, Descrizione di tutti $i$ vescovi ed arcivescovi di Zara dall' anno 388 in sequito, fino il 1774, Znanstvena Knjižnica u Zadru, Ms 739, fol. 15ㄴ $-16^{\mathrm{r}}$. La ceremonia della colomba je kratko scensko prikazanje kako bi prisutni vjernici mogli vidjeti što se dogodilo na rijeci Joradnu kod Isusova krštenja. Pošto ga je Ivan Krstitelj krstio spustio se na Isusovu glavu Duh Sveti u znaku golubice. Jerko BEZIĆ, Razvoj glagoljaškog pjevanja na zadarskom području, Zadar, 1973., str. 174-175.
} 
Sljedeća odredba odnosi se izričito na državne službenike koji su skoro svi dolazili s mletačkih laguna i naslovljena je $O$ onome što treba učiniti poglavarstvo Republike, ${ }^{96}$ čije je provođenje u praksu bilo otežano. Odluka je dodirivala odnos crkvene i državne administracije, a upravo je mletačka vlada rezervirana prema promjenama koje je donio Tridentski sabor. Ona nikada nije službeno prihvatila odluke toga sabora i zbog toga je često dolazilo do sukoba između Rima i Venecije. Otvoreni prekid između Crkve i države, koji će označiti razdoblje prosvjetiteljstva i revolucija, već je tinjao duže vrijeme. On već pokazuje prve znakove sekularnog uporišta društvenih teorija, što je Crkva pokušavala na sve moguće načine preduhitriti. Njih se nije moglo više ušutkati, a postalo je samo pitanje vremena kada će isplivati na površinu. Negativni odgovor rimske administracije na takav razvoj pokazao je već 1607. godine interdikt pape Pavla V. (1605. - 1621.) protiv Mletačke Republike, koji je puno više štetio Crkvi, njezinu ugledu i njenim institucijama negoli državi. ${ }^{97}$

U sljedećoj odredbi, koja se odnosi na kanonike i klerike, navode se opći propisi o nošenju kleričke odjeće, koji se sadržajno ne razlikuju previše od sinodalnih odluka koje su već prije sadržajno pripremljene na dijecezanskim sinodama, osobito onom iz 1566. godine, koju je sazvao zadarski nadbiskup Muzio Callini. ${ }^{98}$ Obje su odredbe inspirirane smjernicama Tridentinskog sabora: kanonicima i ostalim klericima izričito je naređeno svakodnevno nošenje njihove kleričke odjeće. U isti mah im se zabranjuje kockanje i kartanje, sudjelovanje na raznim profanim igrama (igranje i plesanje u kolu), noćnim sastancima, noćno pjevanje pjesama, koje su često imale ljubavni karakter. Taj podatak jasno ukazuje na činjenicu da su i oni kao i drugi građani sudjelovali na različitim igrankama i noćnim susretima. Njima se isto tako zabranjuje bavljenje bilo kojom vrstom trgovine (osobito se zabranjuje preprodaja radi zarade) i nošenje oružja, jer ono isto tako nije spojivo s njihovim kleričkim pozivom: »Budući da ne dolikuje službenicima Kristovim, svećenicima i klericima da trate vrijeme, nego na njih prije spada da molitvom, izlaganjem svetih knjiga i primjerom života poučavaju narod, potpuno im je zabranjeno kockanje i kartanje; neka ne prisustvuju zabavama ili igrama kola, ne bave se lovom, ne hodaju s obrazinama, ne nose oružja. U svemu tome, ako tko pogriješi, neka ga biskup kazni«. ${ }^{99}$

Kanonicima je u posebnoj odredbi naloženo striktno opsluživanje njihovih kanoničkih obveza. ${ }^{100}$ Njihove su obveze prema mjesnom ordinariju i katedralnoj crkvi točno nave-

${ }^{96}$ De his quae a Republicae magistratibus praestari debent. D. FARLATI, Illyricum sacrum, sv. 5, str. 134135; V. BLAŽEVIĆ, Concilia et synodi, str. 52; ISTI, Crkveni partikularni sabori, str. 106; Z. STRIKA, »Zadarske sinode«, str. 86.

${ }^{97}$ Usp. Carlo Pio DE MAGISTRIS, Per la storia del componimento della contesa tra la Repubblica Veneta e Paolo V: (1605-1607), Documenti, Carlo CONTESSO (ed.), Turin, 1941.; Volker REINHARDT, Pontifex. Die Geschichte der Päpste; von Petrus bis Franziskus, München, 2017., str. 606-607.

98 Z. STRIKA, »Die Diözesansynode von Zadar«, str. 285-288.

${ }_{99}$ De iis, quae ad canonicos et clericos in universum spectant. Latinski orginal glasi Cum non doceat ministros Christi, sacerdotes et clericos tempus terere, quin potius ad eos pertinet precibus, et sacrorum librorum explicatione, vitaeque exemplo populos instruere, ludus alearum et taxillorum illius prorsus sit prohibitus: non intersint spectaculis aut choreis, non dent operam venationibus, non incedant personati, aut arma deferant, in quibus omnibus si deliquerint, ab episcopo puniantur. D. FARLATI, Illyricum sacrum, sv. 5, str. 136. Usp. V. BLAŽEVIĆ, Concilia et synodi, str. 52; ISTI, Crkveni partikularni sabori, str. 106.

${ }^{100}$ De iis, quae ad canonocos separatim pertinent. D. FARLATI, Illyricum sacrum, sv. 5, str. 136; V. BLAŽEVIĆ, Concilia et synodi, str. 53; ISTI, Crkveni partikularni sabori, str. 106; Z. STRIKA, »Zadarske 
dene: obvezna služba kora u katedrali i slavljenja svetih misa, zatim pomaganje mjesnom biskupu u upravljanju biskupijom i izvršavanje drugih liturgijskih službi u gradskoj prvostolnici. Na te se poticaje nadovezuje zabrana imenovanja pojedinih kanonika generalnim vikarima. ${ }^{101}$ Odredba je, doduše unesena u saborske akte i vjerojatno je donesena po osobnom Valierovu naputku, ali joj nad/biskupi dalmatinskih biskupija nisu poklanjali baš previše pažnje, dapače, u tom razdoblju uobičajeno je jedan svećenik iz kaptolskog zbora imenovan generalnim vikarom Zadarske nadbiskupije. Istu su praksu provodili i ninski biskupi, koji su već od biskupa Jurja Divnića osobno boravili u Zadru, ${ }^{102}$ a Nin samo sporadično posjećivali, kao i većina rezidencijalnih biskupa u mletačkoj Dalmaciji, tako da je ta saborska odluka ostala mrtvo slovo na papiru.

Sabor je ustao protiv rasprostranjenog kleričkog konkubinata i „divljih brakova“ pa strogo zabranjuje stanovanje žena u domaćinstvu jednog svećenika, bez izričite biskupove dozvole, ili pak njegova generalnog vikara: »neka nitko ne dopusti da u njegovoj kući stanuje ženska osoba čiji izgled potiče na nesuzdržljivost, iz čega može nastati sablazan, nego koja je prokušanog vladanja i koja, po sudu biskupa ili njegova vikara, ne može pobuđivati nikakve sumnje « ${ }^{103}$. Očigledno je odredba donesena iz konkretne prakse jer pred sudom biskupa Valiera našli su se klerici kojima se predbacivalo da žive nemoralno i ne obdržavaju svećenički celibat. Jedni su neopravdano optuženi i oslobođeni optužaba, dok su drugi osuđeni. Tako je u Šibeniku osuđen dominikanac Augustin Pridojević. ${ }^{104}$ Biskupi često nisu znali i nisu mogli sami riješiti takve slučajeve, kako se vidi na primjeru poznatog hrvatskog pjesnika i novigradskog župnika Jurja Barakovića (1548. - 1628.), ${ }^{105}$ ili pak zadarskog kanonika Šimuna Benje, koji je čak imao nekoliko javnih ljubavnica. Upravo ga je zbog njegova nemoralnog ponašanja nadbiskup Minuccio Minucci (1596. - 1604.)

sinode«, str. 86. Točne propise o kanonicima Stolnog kaptola u Zadru donijeli su skupovi gradskog klera koje je 1393. i 1395. godine sazvao nadbiskup Petar Matafar (1376. - 1398.). D. FARLATI, Illyricum sacrum, sv. 5, str. 104; Tadija SMIČIKLAS, Codex diplomaticus regni Croatiae, Dalmatiae et Slavoniae, vol. 17: diplomata annorum 1386-1394. continens, Stjepan GUNJAČA (ur.), Zagreb, 1981., str. 555-556, br. 389.

${ }^{101}$ D. FARLATI, Illyricum sacrum, sv. 5, str. 132.

${ }^{102}$ Biskupu je Grguru Divniću (1475. - 1523.) papa Inocent VIII. (1484. - 1492.) podijelio 10. travnja 1486. godine specijalnu dozvolu (dispensatio) boravka u susjednom Zadru: kao razlog navode se loše klimatske prilike. Papa je isto tako dozvolio biskupu da može obavljati jurisdikciju nad vjernicima njegove biskupije koji obitavaju na teritoriju Zadarske nadbiskupije. Istodobno u tom dokumentu navodi papa posjede Ninske biskupije, koja je ona imala na teritoriju Zadarske nadbiskupije. Ta odluka svojim sadržajen ne iznenađuje jer je u Zadru već prije pribavljena jedna kuća za biskupa i ona je bila vlasništvo Ninske biskupije. Uz nju je početkom 16. stoljeća nadogradio biskup Divnić kapelu svete Marcele. Usp. Monumenta ecclesiae cathedralis Nonae ex antiquis, et recentioribus etiam scripturis, et documentis canonice, et in forma probanti descripta ab illustrissimo, et reverendissimo domino Francisco de Grassis eiusdem cathedralis episcopo anno domini MDCLXXV, HR-AZDN-17/1, Spisi Kurije/Ordinarijata Ninske biskupije, str. 117-118; Carlo F. BIANCHI, Kršćanski Zadar, sv. 2, Zadar, 2011., str. 198; Josip KOLANOVIĆ, »Zbornik ninskih isprava od XIII do XVII stoljeća«, Povijest grada Nina, Grga NOVAK - Vjekoslav MAŠTROVIĆ (prir.), Zadar, 1969., str. 485-528, ovdje str. 494 i 507.

${ }^{103}$ Nemo mulierem in domo sua habitare permitat, cuius forma ad incontinentiam allici, ex qua scandala oriri possint; sed quae sit probatis moribus, quaeve episcopi aut eius vicarii iudicio nullam incontinentiae suspicionem possitiniicere. D. FARLATI, Illyricum sacrum, sv. 5, str. 136.

${ }^{104}$ Usp. ovdje bilj. 90.

${ }^{105}$ Novigradski župnik Juraj Baraković optužen je da živi u »divljem braku« s Margaretom H. (zvanom Cvitom). Kaptolski prmancir i generalni vikar Ninske biskupije Šime Utković, uime biskupa Horcija Bellottija (1592. - 1602.), opominje ga neka odmah otpusti ženu, što on očigledno nije učinio. Usp. Šime LJUBIČIĆ, »Novi podatci o Jurju Barakoviću«, Zadarska smotra, br. 54 (2), Zadar, 2015., str. 39-44, ovdje str. 43. 
izopćio iz crkvenog zajedništva. ${ }^{106}$ Ta činjenica pokazuje negativnu sliku svećenika, ali »taj moralni poremećaj nije bio rijedak slučaj ni među svećenicima drugih europskih katoličkih zemalja ${ }^{107}$, a vjernici nisu to gledali negativno kako na prvi pogled izgleda, nego su bili tolerantni.

Uz to, preporuča sabor, neka se svi dalmatinski biskupi posebno brinu o slavljenju mladih misa, koje su se u „kasne sate” pretvarale u opću narodnu zabavu. Po Dalmaciji su se mlade mise slavile naveliko i uvriježio se običaj zakupljanja novca u župi za priređivanje svečanosti ako mladomisnik i njegova najuža rodbina nisu bili tako imućni da bi mogli samostalno organizirati proslavu mlade mise. To pak nije bilo kakva novost. Cijela župa je sudjelovala na takvoj svečanosti i u takvim prigodama svećenici bi se uhvatili u kolo s djevojkama i udanim ženama, pjevali pjesme i »jamčano se u takvim prilikama događalo štošta zazorno, te je sinod ... preporučio biskupima neka nastoje ukinuti taj običaj« «108.

U odredbi koja se odnosi na župnike i njihove dužnosti ( $O$ onome što spada na župnike), ponavljaju se odluke Tridentinskog sabora i djelomično odredbe o klericima općenito tog sabora. Njima se nalaže dužnost boravka u povjerenim župama, strogo im se zabranjuje bavljenje trgovinom i novčanim poslovima, kockanjem, prisustvovanje igrama i plesanje u kolu te uporaba ili nošenje oružja. ${ }^{109}$ Istodobno im se nalaže propovijedanje riječi Božje nedjeljom i blagdanima, podučavanje puka u kršćanskoj vjeri te dolično slavljenje svetih sakramenata po odredbama Tridentskog sabora, koji donosi preuređeni rimski misal. ${ }^{110}$ Osobito se treba dolično slaviti sakrament krštenja i ženidbe te unositi u matične knjige imena krštenika i imena bračnih sudružnika s njihovim kumovima. Prije sklapanja svakog pojedinog braka treba se zaruka po svršetku nedjeljne mise navijestiti tri puta. Sakrament krštenja treba se podijeljivati nedjeljom u župnoj crkvi, a samo ukoliko je neophodno svećenik smije privatno u roditeljskoj kući krstiti novorođeno dijete. Obraćajući se roditeljima, sabor im nalaže neka s krštenjem svoje djece ne odugovlače predugo, nego neka ih donesu na krštenje najkasnije osam do deset dana poslije poroda. ${ }^{111}$ Usto se određuje da se za svećenike glagoljaše, koji ne poznaju dovoljno latinski jezik, treba na lingua vernacula, dakle na narodni govorni jezik prevesti Suma sv. Antonina (Summa s. Antonini) ili koji drugi prikladni teološki priručnik. ${ }^{112}$

Poslije tih odredaba raspravljali su prisutni biskupi i o drugim problemima s kojima se susretala Crkva na istočnojadranskoj obali, a šesta odredba naslovljena je $O$ onome što

\footnotetext{
${ }^{106} \mathrm{Na}$ temelju uvida u Minuccijevu korespodenciju Vrandečić navodi: Benju je i službeno izopćio jer je po Minuccijevoj spoznaji jedna žena s njime zatrudnjela (ingravitata una Donna). Uz to je imao i drugu, koju je držao u jednoj svojoj kući na otoku, s kojom je već imao djece, a spavao je i s drugim ženama. Kada mu je Minucci naložio da otjera ženu na otoku, odgovorio mu je da kuća nije njegova, nego bratova. Zabranio mu je ići na otok i na druga dva gdje je također spavao sa ženama. J. VRANDEČIĆ, Zadarski nadbiskup, str. 219. ${ }^{107}$ T. PERINČIĆ, »Prilog istraživanju«, str. 161, pozivajući se na L. i M. M. TACCHELLA, Il cardinal, str. 76.

${ }^{108}$ T. MATIĆ, Iz hrvatske književne baštine, str. 106.

${ }^{109}$ De iis, quae ad parochos pertinent. D. FARLATI, Illyricum sacrum, sv. 5, str. 136-137; V. BLAŽEVIĆ, Concilia et synodi, str. 53; ISTI, Crkveni partikularni sabori, str. 106; T. MATIĆ, Iz hrvatske književne baštine, str. 100-101.

${ }^{110}$ D. FARLATI, Illyricum sacrum, sv. 5, str. 136-137; V. BLAŽEVIĆ, Concilia et synodi, str. 53.

${ }^{111}$ D. FARLATI, Illyricum sacrum, sv. 5, str. 137; V. BLAŽEVIĆ, Crkveni partikularni sabori, str. 106.

${ }^{112}$ D. FARLATI, Illyricum sacrum, sv. 5, str. 136; L. JELIĆ, Fontes, d. saec. XVI, str. 34; A. R. FILIPI, »Popovi glagoljaši«, str. 142; S. KRASIĆ, Počelo je u Rimu, str. 226.
} 
spada na djelatnike. ${ }^{113}$ Ona svojim sadržajem odskače od prijašnjih zaključaka, a inspirirana je 9. odredbom s 22. sjednice Tridentskog sabora od 17. rujna 1562. godine i odnosi se na dolično upravljanje crkvenim dobrima, dajući konkretne smjernice o izboru administratora crkvenih dobara i na koji način on treba obnašati svoju službu. ${ }^{114}$ Njezin sadržaj proizlazio je iz konkretne situacije i sabor je pokušao zaštiti crkvena dobra kako se ona ne bi nerazumno na sve strane raznosila i ostala bez kontrole. Bilo je jako mnogo onih (osobito poslije otomanskih osvajanja) koji su usred takvih neprilika nepravedno prisvajali crkvenu imovinu te je saborska odluka svojim sadržajem pokušala preduhitriti njezino brzopleto otuđivanje i nepotrebno komadanje. Koliko je odluka imala uspjeha i koliko je provedena u konkretnoj stvarnosti, pitanje je na koje adekvatan odgovor još nije moguć. U svakom slučaju pokušaji nelegalnog prisvajanja crkvene imovine održali su se po Zadarskoj biskupiji dugo vremena, čak do današnjih dana.

Koncilska odredba $O$ onome što spada na monahinje ${ }^{115}$ sadržajno se odnosi na monaško-redovničke zajednice u cijeloj Dalmaciji. Prisutni biskupi su zahtijevali obdržavanje stroge samostanske klauzure i provođenje religiozne stege te se redovnicama nadređuje da u nepoznavanju latinskog jezika čitaju knjige crkvenih otaca na hrvatskom jeziku. Kako bi se taj zaključak mogao djelotvornije provesti u djelo, određeno je da se za njih prevede na hrvatski jezik Regula sv. Benedikta i ona sv. Franje. Uz njih neka one redovno čitaju na svojem jeziku i druga djela svetih otaca, osobito među njima Ad sororem sv. Benedikta i De virginitate $\left(O\right.$ djevičanstvu) sv. Ambrozija. ${ }^{116}$ Istodobno se biskupe obvezuje na brigu da se monahinjama propovijeda na onom jeziku koji one razumiju i u svakodnevnom životu upotrebljavaju. Očigledno da hrvatski jezik i ta odredba svojim sadržajem nikako ne iznenađuju, nego pokazuju nacionalnu strukturu pučanstva na istočnojadranskoj obali. Oni zadarski ženski samostani koji su primali monahinje iz domaćih patricijskih obitelji (npr. benediktinski samostan sv. Marije) ili oni samostani koji su primali djevojke iz građanskih i seoskih obitelji upotrebljavali su svakodnevno hrvatski jezik. Jezična barijera nije postojala, a onaj dio stanovništva čiji je materinski jezik bio talijanski i koji se trajno nastanio u Zadru, poznavao je isto tako hrvatski jezik. ${ }^{117}$

\footnotetext{
${ }^{113}$ De iis, quae ad operarios pertinent. D. FARLATI, Illyricum sacrum, sv. 5, str. 137; V. BLAŽEVIĆ, Concilia et synodi, str. 53; ISTI, Crkveni partikularni sabori, str. 106.

${ }^{114}$ Conciliorum Oecumenicorum Decreta, c(urantibus Giuseppe ALBERIGO, Josepho A. DOSSETTI, PericlesP. JOANNOU, Claudio LEONARDI, Paulo PRODI, consultante Hubertus JEDIN), treće izdanje, Bologna, 1973., njemački prijevod: sv. III: Konzilien der Neuzeit, Josef WOHLMUTH (prir.), Paderborn - München - Wien - Zürich, 2002., str. 740; Conciliorum Oecumenicorum Generaliumque Decreta, sv. Pavia-Siena (869 - 1424), Alberto MELLONI (prir.), Turnhout, 2013.: sv. III: The Oecumenical Councils of the Roman Catholic Church from Trient to Vatican II (1545-1965), Klaus GANZER - Giuseppe ALBERIGO - Alberto MELLONI (prir.), Turnhout, 2010., str. 108.

${ }^{115}$ De iis, quae ad moniales pertinent. D. FARLATI, Illyricum sacrum, sv. 5, str. 137-138; V. BLAŽEVIĆ, Concilia et synodi, str. 53; ISTI, Crkveni partikularni sabori, str. 106.

${ }^{116}$ D. FARLATI, Illyricum sacrum, sv. 5, str. 138; L. JELIĆ, Fontes, d. saec. XVI, str. 34; A. R. FILIPI, »Popovi glagoljaši«, str. 142. Orginalni tekst danas je dostupan u kritičkom izdanju koje je priredio Ignazio Cazzaniga. S. AMBROSII MEDIOLANENSIS, De virginitate, liber unus, Corpus Scriptorum Latinorum Paravianum, Turin, 1954.

${ }^{117}$ Zadarski nadbiskup Minucije de Minuccio (1596. - 1604.) ukazao je na problem jezične barijere. U pismu prijatelju Ivanu Francescu Caretoniju naveo je nadbiskup, da mu je »nepoznavanje slavenskog (tj. hrvatskog - op. a.) jezika vrlo nepodnosno i povećava poteškoće oko uspješnog rada«. D. FARLATI, Illyricum sacrum, sv. 5, str. 144 .
} 
Osma saborska konstitucija dodirnula je pitanje bratovština, koje nisu samo vjersko-humanitarne nego i socijalno-gospodarske udruge gradskih pučana i patricija, a od 12. do 19. stoljeća u gradu Zadru utemeljeno je čak 65 bratovština: od toga su 42 vjerske, a 23 obrtničke. ${ }^{118}$ Koliko ih je postojalo po pojedinim župama nije poznato, a to bi pitanje zavrijedilo jednu opširniju studiju. Mjesnim biskupima nalaže se neka pomno prate djelovanje svih pojedinih vjerskih bratovština, a njihovim članovima naređuje se opsluživanje statuta (pravila), osobito im se nalaže razumno upravljanje njihovim materijalnim dobrima. Djelotvornije godišnje kontrole trebale su se provoditi preko skupština na kojima se trebaju voditi protokoli. S druge strane, ne zanemaruje se njihova izrazita religijska komponenta, tj. njihova pobožnost, molitva, pobožna djela i druge vjerničke prakse svake pojedine bratovštine. ${ }^{119}$

Posljednja saborska konstitucija odnosi se na vjernike laike obaju spolova te na način njihova spolnog, obiteljskog i bračnog života. Onima koji zajedno žive bez sklopljenog braka (tzv. nezakoniti ili divlji brak) prijeti se oštrom kaznom izopćenja iz kršćanskog zajedništva. ${ }^{120}$ Očigledno je takva praksa iz više razloga bila po Dalmaciji rasprostranjena. U prvom redu su neophodni veliki materijalni izdaci kod upoznavanja i zaruka gošćenjem rodbine, a zatim same svadbe koje su potrajale danima. Njih mnogobrojni zaručnici nisu mogli financijski podnijeti pa su se odlučivali na drugi način preduhitriti izdavanje tako velikih materijalnih troškova, a to zapravo znači da su živjeli sa svojim suprugama bez crkvenog vjenčanja. Njih je dakle, na taj korak tjerala više nužda, bijeda i neimaština negoli nehaj ili protivljenje crkvenim odredbama.

Što se pak tiče samog svećeničkog konkubinata, teško je nešto detaljnije reći dok se sustavnije ne istraži to pitanje. Registri rimskih arhiva, gdje su uneseni podatci o podnesenim molbama za oslobođenje od defectus natalium, tj. izvanbračnog rođenja, koji su dostatni kao i oni u nad/biskupijskim arhivima u Dalmaciji, mogli bi dati objektivniju sliku konkretne situacije, pa s pravom navodi Petar Runje da je bilo »propusta na tom području«, (tj. neodržavanje svećeničkog celibata - op. a.) »ali bila je, čini se, i neobično velika tolerancija. Vjernici su dobro razlikovali svećeničku službu od svećeničkog života. Mnogo je slučajeva gdje su svećenici i službeno ozakonjivali svoju djecu i ostavljali im svoje privatno vlasništvo. Brinuli su se i o svojoj djeci. Tako svećenik Slavko Stojčić iz Karina 5. veljače 1397. daje svoga sina Juanusija kod Dragoša pok. Jurja, postolara, neka ga nauči kroz tri godine postolarski zanat. Pri sastavljanju javnoga bilježničkog spisa 20. listopada 1401. prisutan je i Luka, drvodjelac, sin svećenika Buška«. ${ }^{121}$ Ni održavanje sabora u Baselu i nešto više od stotinu godine kasnije u Tridentu nije bitnije utjecalo na održavanje svećeničkog celibata: velik dio svećenika u mletačkoj Dalmaciji ga je održavao, a jedan manji dio nije. Tako svećenik Matija Danilović, župnik mjesta Polačina u Ninskoj biskupiji svjedoči 13. veljače 1590. godine pred javnim bilježnikom: »Tri svećenika žu-

\footnotetext{
${ }^{118}$ Opširniji pregled zadarskih bratovština prikazao je Cvitanović. Usp. ovdje bilj. 93.

${ }^{119}$ De iis, quae ad confraternitas pertinent. D. FARLATI, Illyricum sacrum, sv. 5, str. 138; V. BLAŽEVIĆ, Concilia et synodi, str. 53; ISTI, Crkveni partikularni sabori, str. 106.

${ }^{120}$ De iis, quae ad laicos pertinent. D. FARLATI, Illyricum sacrum, sv. 5, str. 138; V. BLAŽEVIĆ, Concilia et synodi, str. 53; ISTI, Crkveni partikularni sabori, str. 106.

${ }^{121}$ P. RUNJE, Glagoljica u zadarskoj nadbiskupiji, str. 125 pozivajući se na HR-DAZD, SZN, Petrus de Sercana, sv. 4, svešč. 64 (5. veljače 1397.).
} 
pnika s područja Banovine i Like, koje se nalazi pod turskom vlašću, a gdje se nalazi još desetak svećenika, žive u javnom konkubinatu s priležnicama; želi li ih se kazniti ili odmaknuti odatle, potrebno je pronaći im zamjenu, što nije moguće. Stoga se moli za potrebu njihova oporavka«. ${ }^{122}$

Upravo doneseni podatci ukazuju na konkretnu situaciju i pogled na seksualnost, koja se prema crkvenom nauku trebala isključivo živjeti u zakonito sklopljenom braku. To očigledno nje bila baš uvijek praksa. Sinodalna odredba istodobno je usmjerena protiv kleričkog konkubinata i laičkog divljeg braka pa se nalaže mjesnim biskupima neka se u slučaju potrebe primjenjuje kazna izopćenja iz crkvenog zajedništva. Isto tako se kude roditelji koji drže svoje kćeri zatvorene u kući zbog pogibelji, otmice ili da se ne bi ćudoredno iskvarile. Njima se strogo nalaže neka se pobrinu kako bi one u pratnji svoje majke ili nekoga od bližih rođaka barem nedjeljom mogle prisustvovati misnom slavlju. ${ }^{123}$

Sabor se 20. svibnja obratio Kongregaciji za biskupe, svećenike i redovnike s molbom za pomoć tiskanja jednog teološkog priručnika, a ona je na svojem jesenskom zasjedanju obećala finacijsku potporu. ${ }^{124}$ Član Kongregcije je bio kardinal Guido A. Santoro di Santa Severina, koji je o projektu tiskanja razgovarao 12. studenoga 1579. godine s Grgurom XIII. Papa je ipak pomalo oklijevao, bio je nesiguran i želio se očigledno prije negoli se odluči posavjetovati s pojedinim biskupima iz Dalmacije. Na poziv dotične Kongregacije nadbiskup zadarski Venier poslao je kanonika Šimu Budinića (1535. - 1600.) u Rim. Taj je u Vječnom gradu boravio od srpnja 1581. do lipnja 1583. godine, gdje je dovršio prijevod knjige Summa doctrinae christianae (Suma navka christianskoga) nizozemskog isusovca Petra Kanizija (1521. - 1597.) i Breve directorium ad confessarii (Ispravnik za erei ispovidnici i za pokornih) španjolskog isusovca Ivana Vladislava Polanca (Juan Alonso Polanco (1517. - 1576.). Posljednje spomenuto djelo tiskano je u Rimu 1582. godine latiničkim slovima. ${ }^{125}$

\section{Zaključak}

Kada je obišao sve biskupije južnije od Zadra, sazvao je vizitator Valier pokrajinski sabor dalmatinskih biskupija pod mletačkom upravom u benediktinskom samostanu sv. Krševana. On je u kratkom razdoblju od nekoliko mjeseci mogao upoznati konkretnu situaciju na istočnojadranskoj obali, a u više biskupija je osobno sudjelovao na dijecezanskim sinodama, pa je u osobnom susretu s biskupima, svećenicima i vjernicima mogao dobiti više

\footnotetext{
${ }^{122}$ Hrvatski prijevod donosi Š. LJUBIČIĆ, »Novi podatci«, str. 41.

${ }^{123}$ Hortantur patres huius conventus omnes patres et matres familias, ne in privatis domibus filias suas inclusas teneant ita, ut sanctissimo misae sacrificio nunquam intersint; ut ad ecclesiam dominicis saltem diebus illas ad missam accedere permittant sub matrum et consanguineorum custodia. D. FARLATI, Illyricum sacrum, sv. V, str. 138. Taj saborski zaključak proizlazio je iz svakodnevnog života u Dalmaciji kada se krađa djece na osmansko-mletačkoj granici zbivala svakodnevno, pa su roditelji, kako bi ih zaštitili (osobito djevojke), prisiljeni pristupati takvim drastičnim mjerama.

${ }^{124}$ T. TRSTENJAK, »Hrvatski katekizmi«, str. 346, 274.

${ }^{125}$ Usp T. TRSTENJAK, »Hrvatski katekizmi«, str. 346-347; 274-275. Šime Budinić preveo je na hrvatski jezik Rimski katekizam pape Pia V. koji nije tiskan, a prvo izdanje Rimskog katekizma na hrvatskom jeziku pojavilo se 1775. godine u prijevodu kotorskog svećenika Josipa Matovića. Franjo E. HOŠKO, Negdašnji hrvatski katekizmi, Zagreb, 1985., str. 109.
} 
informacija o konkretnoj situaciji svake pojedine biskupije. Iz tog razloga njegovi zapisi predstavljaju svjedočanstvo čovjeka suvremenika koji je, objektivno i bez predrasuda, prikazao gospodarsko-političke i ćudoredno-vjerske prilike u mletačkoj Dalmaciji. Iz njegova izvješća može se nazrijeti teško stanje mletačke Dalmacije. S jedne strane crkvene službe i njihovu aktivnost sputavala je mletačka vlast, koja ih je pokušavala podrediti svojim vlastitim interesima, a s druge strane su Osmanlije, koji su više štete nanosili za vrijeme mira negoli za vrijeme ratnih razračunavanja. Upravo u takvoj situaciji sazivao je biskup Valier sabor u Zadru koji je najsigurnija mletačka utvrda u Dalmaciji i biskupi su morskim putem nesmetano mogli doploviti do njega. Preko njega je biskup Valier poticao neophodnu obnovu crkvene prakse, opominjao je nad/biskupe i kler neka obdržavaju crkvene propise i neka uzorno predvode povjereni narod. Usto nalaže nad/biskupima ukoliko ne poznaju dovoljno hrvatski jezik neka se potrude što prije ga naučiti kako bi mogli osobno propovijedati povjerenim vjernicima. Kako bi se mogla djelotvornije provoditi obnova crkvenih struktura, određeno je neka se metropolitanski sabori sastaju svake treće godine, dok su biskupijske sinode trebale zasjedati jednom godišnje. Hvale vrijedan pokušaj biskupa Valiera ostao je samo mrtvo slovo na papiru. Prisutni nad/biskupi po dalmatinskim biskupijama nisu imali sluha za njegov poticaj. Tijekom druge polovice 16. stoljeća nisu redovno održavali dijecezanske sinode, a od sredine 17 . stoljeća samo sporadično.

\section{SUMMARY \\ THE PARTICULAR COUNCIL OF THE SOUTHERN CROATIAN DIOCESES \\ IN ZADAR 1579}

The Bishop of Verona, Agostino Valier, who was assigned by Pope Gregur XIII (15721585) to travel to Dalmatia, shortly visited the Dalmatian dioceses, which were under Venetian administration. After visiting all the Venetian administered dioceses in Zadar's Southern region and the church of Zadar and Nin, Valier called for a Particular Council, held in Zadar's Benedictine Abbey of St. Chrysostomus in mid-May 1579. Subsequently, Valier visited the three remaining dioceses (on Krk, Rab, and Osor), summarized in Valier's detailed report, found in the Vatican Archive. There, the apostolic visitor describes the ecclesiastical situation in Dalmatia with which the Ottomans as well as the Venetian administration interfered seriously. Both Ottomans and Venetians tended to utilize ecclesiastical structures for their political purposes.

The Particular Council issued nine decrees - inspired by the Council of Trent. The first decree refers to bishops, who were obliged to reside in the dioceses and learn the language of the believers in order to preach to believers in their native language. Concurrently, the bishops assembled emphasized that it was necessary to found two seminaries in Dalmatia: one in Zadar and one in Split.

Moreover, additional decisions pertained to the clergy and the dioceses, namely: The clerics were prohibited to play cards; clerics were not allowed to sing secular songs nor to attend dance events at night; the nuns were required to strictly follow monastic rule, and it 
was ordered that, for nuns, books should be translated into Croatian; and believers were expected to adhere to Christian duties and to baptize their newborns within eight to ten days after giving birth.

By and large, the assembled council adapted the Tridentine renewal to the ecclesiastical situation in Venetian governed Dalmatia. The decrees were encouraged before by several diocesan synods in the dioceses; however, at this time, decrees held validity throughout the entire region. Bishops were able to play a key role in order to teach the Christian faith to the people. If they were not able to do so in terms of language skills, they were to learn the believers 'language as soon as possible.

KEY WORDS: Zadar, Catholic Church under Venetian administration, apostolic visitation, particular council, apostolic visitor Agostino Valier, early modern times. 
